\title{
Analysis of crater formation in buried NG pipelines: A survey based on past accidents and evaluation of domino effect
}

\author{
J. Giovanni Ramírez-Camacho, ${ }^{\mathrm{a},}$, Elsa Pastor ${ }^{\mathrm{a}}$, Rafael Amaya-Gómez ${ }^{\mathrm{b}}$, Christian Mata ${ }^{\mathrm{a}}$, \\ Felipe Muñoz ${ }^{\mathrm{b}}$, Joaquim Casal ${ }^{\mathrm{a}}$ \\ ${ }^{a}$ Centre for Technological Risk Studies (CERTEC), Barcelona East School of Engineering \\ (EEBE), Universitat Politècnica de Catalunya - BarcelonaTech (UPC). Eduard Maristany \\ 10-14, 08019-Barcelona, Catalonia, Spain. \\ ${ }^{b}$ Department of Chemical Engineering, Universidad de Los Andes. Carrera 1 No. 18A-10, \\ Bogotá, Colombia.
}

\begin{abstract}
The formation of a crater by the abrupt and catastrophic rupture of a high-pressure pipeline can be highly relevant, especially when the crater uncovers other pipelines, which could undergo a domino effect with a significant increase of the consequences on people or on the environment. However, this scenario has been only partially studied in the literature. To assess the influence of the pipeline parameters on the dimensions of the resulting crater, a statistical analysis of accidental ruptures of buried natural gas pipelines that have involved the formation of a crater was carried out. Mathematical expressions are proposed to describe the proportionality relationships found, which can be very useful to support adequate separation distances in the design and construction of parallel corridors of pipelines after appropriate escalating effects are considered. Finally, detailed event trees were developed to calculate the probability of occurrence of the final outcomes, as well as the identified domino sequences, based on a qualitative and quantitative analysis of the data. The study of these accident scenarios, based on actual cases, represents a useful and needed advance in risk analysis of natural gas transportation through pipelines.
\end{abstract}

Keywords: Natural gas; Buried pipeline; Pipeline rupture; Crater formation; Domino effect

\section{Introduction}

High population growth and rapid industrialization around the world have led to a substantial increase in the consumption of Natural Gas (NG). Consequently, the NG transportation through high-pressure pipelines to ever-greater distances has also been increased (EGIG, 2015). According to the U.S. Energy Information Administration (EIA, 2017), the world consumption of NG increased due to rapid economic growth from 1499 billion cubic meters (BCM) in 1980 to 3476 BCM in 2014, representing an increase of $132 \%$. To address this challenge, the gas industry usually maximizes its transport capacity by increasing the operating pressure of the system or by installing more pipelines, often parallel or crossing to existing ones. These pipelines transport gas or oil over great distances and sometimes they are closely separated between them, which imply a particular risk associated with the potential interaction of these systems (Acton et al., 2010; Wang et al., 2011). In these situations, a Loss of Containment (LOC) may affect a close pipeline or other structure located around the site of an accident, aggravating the corresponding consequences of the event. This type of events has happened in different accidents with

\footnotetext{
* Corresponding author. Tel.: +34 934016675

E-mail addresses: ambientalunadm@nube.unadmexico.mx (J.G. Ramírez-Camacho)
} 
severe consequences on people or with significant material and economic losses (RamírezCamacho et al., 2015).

Due to its physical and chemical characteristics, NG presents several risk scenarios depending on whether it is ignited or not. If it ignites immediately after the release, a jet fire will occur. If there is no ignition, the gas will disperse into the atmosphere as toxic dispersion. A flash fire or a gas cloud explosion, followed by a jet fire, is possible if the ignition is delayed. These risk scenarios also depend on the release mode (i.e., full-bore rupture, leak/puncture), as well as the volume of gas released, the meteorological conditions at the time of the accident, and the characteristics of the surroundings (i.e., urban, rural). Therefore, to ensure the integrity of NG pipelines, it is necessary to rigorously evaluate all possible hazardous scenarios and their consequences, mainly on people but also on the environment, because safety and environmental impact must have absolute priority over the demand of NG.

About the possible accidental scenarios that can occur as a result of buried NG pipelines, the formation of a crater by the rupture of a high-pressure pipeline has been reported by a limited number of publicly available studies. The formation of such a crater can be a relevant event, especially if it can imply a domino effect on other parallel or crossing pipelines uncovered by the initial rupture, thus increasing significantly the scale of the accident and its consequences on people or the environmental impact (Hemmatian et al., 2014).

Published research has focused on studying the crater formation mechanism and its dimensions but in underground explosions of TNT (Ambrosini et al., 2002;

Ambrosini and Luccioni, 2006; Luccioni et al., 2009; Xin-zhe et al., 2013; Krishna et al., 2016). However, only a few studies have specifically focused on the formation of craters by the explosive rupture of buried pipelines. Bartenev et al. (1996) analysed accidental ruptures in the Central Asia-Centre gas pipeline system, which run from Turkmenistan via Uzbekistan and Kazakhstan to Russia. They found a direct relationship between the rupture length of the pipeline and the length of the crater. Acton et al. (2010) developed a framework based on experimental data, for determining appropriate design separation distances between buried parallel gas pipelines, including the maximum dimensions of the crater formed by pipeline ruptures. Silva et al. (2016) analysed the ruptures of underground petroleum product pipelines with the formation of a crater and proposed a model to predict the crater width as a function of the design pipeline parameters and the soil density. Laheij et al. (2017) studied the minimum distances between parallel pipelines in corridors located in the Netherlands. Recently, Amaya-Gómez et al. (2018) proposed a probabilistic prediction of the crater width and depth based on NG losses of containment in underground pipelines.

Nowadays, it is recognized the significance of historical analysis of past accidents as a source of valuable information on their main aspects (Lindberg et al., 2010; Kletz, 2011; Siler-Evans et al., 2014; Hemmatian et al., 2014; Lam, 2015; Ramírez-Camacho et al., 2017). In this paper, a historical survey of accidents in buried NG pipelines that have involved the formation of a crater was carried out with the aim of analysing the crater formation and its influence on possible domino effect scenarios. For this purpose, statistical analyses were implemented to study the influence of pipeline geometric (diameter), operating (pressure), installation (burial depth), and accident (rupture length) parameters on the dimensions of the crater. A qualitative and quantitative analysis of the 
data was considered to develop detailed event trees for intermediate and final events following the accidental release of NG from pipelines. These trees delineate the domino sequences after the formation of a crater and estimate the probability of occurrence of these scenarios. The study of these accident scenarios, based on actual cases, represents a useful and needed advance in risk analysis of NG transportation through pipelines.

In this paper, a set of 90 accidents related to the formation of craters involving underground NG pipelines is analysed (circumstances, crater dimensions, domino effect, final outcomes). The document is structured as follows: Section 2 describes how craters are formed. Section 3 presents the data gathered for this analysis. Section 4 describes the proposed methodology based on an exploratory analysis of the data gathered, which evaluates the influence of the pipeline parameters on the crater dimensions afterward, and the conditional probabilities once a loss of containment take place. Section 5 presents the results and discussions. Some concluding remarks are given in Section 6, and finally, future perspectives are described in Section 7.

\section{Crater formation by the rupture of a buried pipeline}

A crater is produced instantaneously after an explosive event takes place. The explosion causes the fracture, compaction and plastic deformation of the soil close to the pipe. The result is the formation of a bowl-shaped cavity by the displacement and ejection of material from below the ground surface. The dimensions of the crater formed will define the size of the area that would be affected. In the case of the rupture of a buried NG pipeline, the parameters that can influence the size and shape of the crater formed are those related to the pipeline itself (e.g., diameter, internal pressure), and to the external conditions like the depth of burial of the pipeline and the soil characteristics (Tonelli and Aparício, 2005).

A classic crater configuration is depicted in Fig. 1. The considered crater dimensions are based on those defined by Hansen et al. (1964) and Cooper (1996). $D_{a c}$ represents the apparent crater diameter, $D_{t c}$ is the true crater diameter, $H_{a c}$ is the apparent depth of the crater and $H_{t c}$ is the true depth of the crater. Concerning the pipeline parameters, $D$ denotes the outer diameter, $B_{d}$ is the burial depth and $L_{r}$ concerns to the length of rupture of the pipeline. The term "true crater" refers to the crater formed immediately after the pipeline rupture. Following the rupture, part of the ground ejected falls back into the newly-formed crater to form the "apparent crater" (final crater configuration), whilst another portion of ground, even sections of pipe, is expelled at a certain distance away from the rupture site. The true crater is deeper than the apparent crater; however, it is a hard task to make a direct physical measurement of the true crater in practice. For this reason, the measurements taken after an explosive event are those of the apparent crater.

\subsection{Causes and energy involved}

The formation of a crater can be caused by the abrupt and catastrophic rupture of highpressure pipeline produced by a line failure (e.g., a mechanical failure) or by the explosive ignition of accumulated gas leaking from a small hole in the pipe wall (a weld cracking, corrosion pinhole or puncture). However, the probability that the leaking gas flow through the soil enters the atmosphere and accidentally catches fire, explodes and ruptures the pipeline is very low (IGEM, 2012). Notwithstanding, if the size of the defect or puncture exceeds a certain "critical" length (in pipeline longitudinal direction), then the pipeline could rupture catastrophically and create a crater (Spoelstra and Laheij, 2011). 
Whatever the cause of the pipeline rupture, the energy involved in the formation of the crater is different in each case. According to Peekema (2013), the rupture of a pipeline caused by the explosive ignition of accumulated NG leaking from a small hole would involve both the compression energy and the chemical energy of the gas. The latter will be available once the gas is present in a mixture with air (i.e., sufficient oxygen) within the explosion limits, together with a source of ignition. The chemical energy available from an explosive gas/air mixture is much higher than the compression energy in the gas; however, the compression energy of the gas could be diminished or, ultimately, lost when the gas leaked from the pipeline. On the other hand, the same author affirmed that in the abrupt and catastrophic rupture of a pipeline caused by a line failure, the energy involved is only associated with the compression energy contained in the pressurized gas, which is released at the moment of rupture. In this case, the escaping gas from the ruptured pipeline could ignite, but not "explode", so the chemical energy of the gas would contribute to the subsequent fire, but not to the explosive rupture.

Once the crater has been formed, the gas escaping from the broken pipeline may have a "scouring effect" and carry away the loose earth or the rock material that finds in its path; it could even eject huge fragments of the pipeline. In this way, the final crater could be much larger than the one formed by either of the previous causes. Therefore, the dimensions of the final crater may also depend on the kinetic energy of the spewing fluid and the duration of the scouring action (Peekema, 2013).

\subsection{Domino effect possibilities}

Once the initial rupture of a buried pipeline (P1) has formed the crater, the possibilities of a domino effect depend on whether a second buried pipeline (P2) lies within the crater limits or not, and whether it transports a dangerous fluid. Another important aspect is whether the gas leaking from P1 ruptured ignites or not. The different possible sequences have been summarized (Fig. 2). The final accidental scenarios of these sequences -pipe failure due to thermal impact or thermal/blast impact- have been based on the historical survey and risk analysis expertise (Ramírez-Camacho et al., 2015).

If $\mathrm{P} 2$ is outside the crater's limits, then it will not be damaged either by the explosive effect or thermal radiation because the surrounding soil will protect it. On the contrary, if P2 is inside the crater formed (whether totally or partially exposed), there are two possibilities for it to fail. The first refers to the possibility that the explosive effect of the rupture of P1 damages P2 (whether a puncture, a crack or a total rupture), causing its failure. In this case, if fluids releasing from both pipelines ignite, the resulting hazard would come from the thermal radiation or direct contact with flames produced by the fire. If there is no ignition, the gas will disperse in the atmosphere, and the soil will be contaminated if P2 transports another liquid.

Alternatively, if the explosive rupture of $\mathrm{P} 1$ did not affect $\mathrm{P} 2$, but the releasing gas from the ruptured $\mathrm{P} 1$ is ignited, there is a probability that $\mathrm{P} 2$ fails due to flames impingement or strong thermal radiation when $\mathrm{P} 2$ conveys a gas. If this pipeline conveys a gas and it is not adequately fireproofed, the probability of failure in a rather short time is very high. However, if $\mathrm{P} 2$ conveys a high flow at high pressure, the heat transfer coefficient to internal fluid could be sufficient to prevent a failure. If P2 conveys two-phase flow, the possibility of pipeline failure due to the high temperature reached by the pipe wall should 
also be considered. Conversely, if $\mathrm{P} 2$ conveys a liquid, it will act as a refrigerant and will cool the pipe wall avoiding its failure. In either case, the flow in P2 can be shut off if blocking valves are shut down; this again could lead to the pipeline failure.

To prevent such domino effect scenarios, safety distances between parallel and crossing pipelines and their surroundings have been proposed in standard or code practices such as that reported for natural gas and water parallel pipelines by the Energy Commission of Malaysia (clearance of $>300 \mathrm{~mm}$ ) or the ASMEB31.8 (clearance of $>6$ in for an underground structure) (Mohsin et al., 2014; Shi et al., 2012). Other approaches like Silva et al. (2016) suggest a $10 \mathrm{~m}$ separation for underground pipelines based on an analysis of historical accidents, and PEMEX (2009) recommend a minimum separation of $1 \mathrm{~m}$ in the same ditch.

\section{Data collection and organization}

Information of ruptures of buried NG pipelines that involved the formation of a crater was collected from accident databases, technical reports, and accident reports. The primary purpose of collecting the available information is to gather all disseminated data on crater accidents in the pipeline natural gas transportation industry and create a reliable database, which may be used to improve the information and understanding about the occurrence of this type of events and to analyse their main characteristics statistically. The main sources of information were:

- The Analysis, Research and Information on Accidents database (ARIA, 2015).

- The Federal Institute for Materials Research and Testing of Germany (BAM, 2009).

- The Major Hazard Incident Data Service database (MHIDAS, 2007).

- The Transportation Safety Board of Canada (TSB, 2015).

- The U.K. Health and Safety Executive (HSE, 2000, 2002).

- The U.S. Pipeline and Hazardous Materials Safety Administration (PHMSA, 2015a).

- The U.S. National Transportation Safety Board (NTSB, 2015).

Where a record of interest was identified, the available data was stored in a database in MS Excel format included as supplementary material. Table 1 shows the fields used to organize the data, which are divided into seven blocks. The information contained refers to the identification of the accidents (date, location, characteristics, and causes), pipeline characteristics, dimensions of the craters, and consequences (injuries, deaths, evacuees). It should be noted that the analysis of the consequences of these accidents has not been the subject of this study, but rather the occurrence of a failure scenario.

Table 1

Structure of the database on accidents in NG pipelines that involved a crater formation.

\begin{tabular}{|c|c|c|c|}
\hline Block & Data field & Type of field & Units \\
\hline \multirow[t]{3}{*}{ 1. Accident identification } & $\begin{array}{l}\text { The ID number of the accident } \\
\text { in the database }\end{array}$ & List & - \\
\hline & Date of occurrence & Date & DD/MM/YYYY \\
\hline & Location & Text & - \\
\hline \multirow[t]{3}{*}{ 2. Pipeline characteristics } & Diameter & Numeric & in \\
\hline & Wall thickness & Numeric & in \\
\hline & Grade & Text & - \\
\hline
\end{tabular}




\begin{tabular}{llll}
\hline Block & Data field & Type of field & Units \\
\hline & Installation year & Date & DD/MM/YYYY \\
& Pressure & Numeric & bar \\
& Type of pipeline & Text & - \\
& Burial depth & Numeric & $\mathrm{m}$ \\
3. Crater dimensions & Length & Numeric & $\mathrm{m}$ \\
& Width & Numeric & $\mathrm{m}$ \\
& Depth & Numeric & $\mathrm{m}$ \\
& Area & Calculated & $\mathrm{m}^{2}$ \\
& Volume & Calculated & $\mathrm{m}^{3}$ \\
4. Characteristics of the & Rupture length & Numeric & $\mathrm{m}$ \\
accident & Distance to pipe fragments & Numeric & $\mathrm{m}$ \\
& Ignition & Text & - \\
& Flames length & Numeric & $\mathrm{m}$ \\
& Time from release to ignition & Numeric & $\mathrm{min}$ \\
5. Nature of accident & Time from release to shut-down & Numeric & $\mathrm{min}$ \\
6. Consequences & Causes & Text & - \\
& Deaths & Numeric & - \\
7. References & Injuries & Numeric & - \\
& Evacuees & Numeric & - \\
\hline
\end{tabular}

During this analysis, the following aspects have to be considered:

- The dimensions registered in the database are those of the apparent crater; that is, the measurements taken after the rupture of the pipeline.

- In Fig. 1, the "Apparent crater diameter" parameter refers to a circular crater. In practice, however, the shape of a crater caused by the rupture of a buried pipeline may not necessarily be circular, mainly due to the axial symmetry of the pipeline and the length of the rupture. To better organize the data, two new fields were added, "Crater length" and "Crater width", replacing the previous one.

- The "Apparent depth of the crater" parameter has been defined in the database as "Crater depth".

- The database contains more information than what is discussed here. The availability of these data can be useful for applying risk analysis tools, generating lessons learned to avoid recurrence of these accidents and identifying those accidents more likely to occur.

Relevant information for the analysis was incomplete or inaccurate in a number of the records extracted. To complete the missing data and to find new accident records, a detailed search was conducted by consulting other free-access sources that cover accidents in pipelines (e.g., newspaper, articles, and websites) and checking the information thus obtained. After applying this extraction process, a collection of 90 accidents related to the formation of craters by the rupture of buried NG pipelines was obtained (see Appendix 1, Table A.1). The records collected cover the period from 1954 to 2015. To the best of our knowledge, this is the largest sample of such accidents gathered in peer-reviewed literature.

\section{Proposed methodology to analyse the crater formation}


Based on the 90 gathered records, this work proposed the following methodology to analyse possible relationships among the pipeline parameters and the crater dimensions. Initially, a preliminary analysis was attempted to extract trends related to the main parameters of the pipeline that determine the energy potential of the accident and causes. Therefore the pipeline diameter, the burial depth, operating pressure, and the length of rupture are compared.

Based on these parameters, the degree of relationship between the crater dimensions (dependent variables) was evaluated through a correlation and regression analyses. In one hand, the correlation study was evaluated using Pearson correlation coefficients $r$. Several alternatives exist to compute the Pearson correlation coefficient, but in this work, the traditional function using raw scores and means was considered (Rodgers and Nicewander, 1988). Besides its easy calculation, this correlation coefficient provides the direction of the correlation (i.e., positive or negative) and supports the selection of independent variables within a linear regression analysis. However, the Pearson correlation coefficient assumes pairwise normal variables, which are linear related, and homoscedasticity (i.e., similar finite variance), so the independent variables could be limited for those fulfilling these assumptions. Therefore, the Spearman correlation $\operatorname{rank} \rho$ was also compared to estimate the strength of the monotonic relationship between the crater dimensions and the pipeline parameters. The Spearman rank is not subjected to any assumption about the distribution of the variables, and it is invariant under monotone transformations. On the other hand, the regression model fit was initially determined based on two well-known numerical measures: the Residual Standard Error (RSE) and the adjusted $R^{2}$ statistic. The first one is an estimate of the standard deviation of the error based on the Residual Sum of Squares (RSS), and the latter is a measure of the linear relationship between the variables and the response. In addition, Confidence Intervals (CI) were considered for the obtained regression coefficients following the reported in Rencher and Schaalje (2008).

Finally, conditional probabilities are estimated based on the accident sequence of the 90 records gathered. These probabilities focus on the possibility of domino effects and the estimation of final outcomes given a loss of containment of a natural gas pipeline.

\section{Results and discussion}

\subsection{Exploratory analysis}

\section{Diameter and type of pipeline}

Fig. 3 shows the distribution of the entries in six categories, according to the nominal diameter of the pipelines involved in cratering accidents: $D<10$ in $(254 \mathrm{~mm}), 10 \leq D<20$ in (508 mm), $20 \leq D<30$ in (762 mm), $30 \leq D<40$ in $(1016 \mathrm{~mm}), D \geq 40 \mathrm{in}$, and unknown diameter. The pipeline diameter is known in $94.5 \%$ of cases ( 85 entries). Of these records, pipeline diameters from 20 to 40 in were the most frequently involved (70.6\%, 60 entries), followed to a lesser extent by pipelines less than 20 in in diameter $(22.3 \%, 19$ entries), and more than 40 in $(7.1 \%, 6$ entries).

Fig. 3 also shows the distribution of the inputs by the type of pipeline. This information is available in $65.6 \%$ of the cases (59 entries). Most of these events (78\%, 46 cases) occurred in transmission lines and, to a lesser extent, in distribution (15.2\%, 9 entries), and gathering $(6.8 \%, 4$ entries) lines. This distribution can be explained and justified by the 
considerable length of transmission lines installed around the world, and also by the smaller diameter and lower operating pressure of distribution lines.

\section{Pipeline burial depth $\left(B_{d}\right)$}

NG pipelines are generally installed shallow under the ground for ease of installation and access during maintenance or repair activities. This approach is especially advantageous since the ground provides a convenient mode of supporting high-pressure pipelines under operating conditions, as well as to protect them from exposure to natural elements (e.g., severe weather, ultraviolet radiation) and from human-induced risks (Wijewickreme and Weerasekara, 2011). However, even in buried pipelines, an inadvertent release could endanger human life, cause damage to property or the environment or represent significant costs.

Fig. 4 represents the distribution of the burial depth of the pipes, according to their diameter and type. This information is known in $55.6 \%$ of cases (50 entries). Of these records, $52 \%$ of the pipelines were buried at depths between 1 and $2 \mathrm{~m}$, while $26 \%$ were installed less than $1 \mathrm{~m}$ depth and $20 \%$ at a depth between 2 and $5 \mathrm{~m}$. Only $2 \%$ of these records (one case) have a depth greater than $5 \mathrm{~m}$. The latter case corresponds to the accident occurred on 13 February 2014 in Adair County, Kentucky (USA), where a 30-in (762 mm) NG pipeline buried at a depth of $9.1 \mathrm{~m}$ was ruptured, forming a crater approximately $18 \mathrm{~m}$ depth by $15 \mathrm{~m}$ width (PHMSA, 2014a).

\section{Operating pressure $\left(P_{o p}\right)$}

The operating pressure is one of the main parameters of the pipeline that determine the energy potential of the accident; however, only $73.3 \%$ (66 cases) of the cases reported this data. The information collected refers to the pressure at which the pipeline was operating at the time of the failure; however, when this data was not specified as such, the operating pressure of the system was taken into account. Fig. 5 illustrates that the trend is to operate at pressures from 40 to 70 bars (79\% of known cases). It can also be observed that the operating pressure increases as the pipe diameter increases. Although the gathering, transmission, and distribution pipelines are designed and constructed to withstand much more pressure than the system could actually reach, it is a fact that the higher the pressure inside the pipeline, the more potentially dangerous it will be a loss of containment.

\section{Rupture length $\left(L_{r}\right)$}

The rupture length is a parameter that requires special attention, because, due to the axial symmetry of the pipeline, it defines the limits of the crater-mainly along-and, therefore, the possible area of destruction. This phenomenon takes place in a three-stage process (initiation of crack, propagation of it and, finally, the total rupture of the line), which is defined by the characteristics of the pipeline (e.g., construction material, age) and the operating pressure. Andrews et al. (2004) point out that the combination of the operating pressure and crack opening angle can result in cracks propagating for $20 \mathrm{~m}$ and longer, at a speed of $200-300 \mathrm{~m} / \mathrm{s}$. The opening angle of the crack was not analysed in this study.

Fig. 6 shows the distribution of the entries according to the rupture length of the pipelines. This information is known only in 50\% of the cases. Most of the ruptures ranged from 1 to 
$30 \mathrm{~m}(82.2 \%, 37$ cases), followed much less frequently by lengths between 30 and 60 (11.1\%, 5 cases), which agree with the indicated by Andrews et al. (2004). Only 2.2\% of these records (one case) had a rupture greater than $100 \mathrm{~m}$ long. This case corresponds to the accident occurred on 21 February 1986 in Kentucky (USA), in which a rupture of a 30in $(762 \mathrm{~mm})$ gas pipeline produced a crater of $152 \mathrm{~m}$ long and $9 \mathrm{~m}$ wide from a longitudinal rupture of $146 \mathrm{~m}$.

\subsection{Principal influences of the pipeline parameters on the crater dimensions}

The correlation results indicate that, for a significance level of 5\%, there are direct or positive relationships between the variables (see Table 2). The values in parenthesis indicate the number of records with information about the parameters, which were used to calculate the corresponding correlation coefficients. The correlation coefficients are not expected to be very high, as the crater dimensions can be simultaneously affected by more than one parameter of the pipeline. Therefore, it is possible to determine with which pipeline parameters a particular crater dimension is most closely related, although the calculated correlation coefficients are relatively low in some cases.

Table 2

Correlation matrix between crater dimensions and pipeline parameters. Pearson coefficients in the lower triangular and the Spearman rank in the upper triangular.

\begin{tabular}{|c|c|c|c|c|c|c|c|}
\hline & \multicolumn{3}{|c|}{ Crater dimensions } & \multicolumn{4}{|c|}{ Pipeline parameters } \\
\hline & Length & Depth & Width & Diameter & $\begin{array}{l}\text { Operating } \\
\text { pressure }\end{array}$ & $\begin{array}{l}\text { Burial } \\
\text { depth }\end{array}$ & $\begin{array}{l}\text { Length of } \\
\text { rupture }\end{array}$ \\
\hline Length & $\begin{array}{l}1.000 \\
(87)\end{array}$ & 0.394 & 0.650 & 0.441 & 0.428 & 0.210 & 0.650 \\
\hline Depth & $\begin{array}{l}0.223 \\
(67)\end{array}$ & $\begin{array}{l}1.000 \\
(69)\end{array}$ & 0.611 & 0.307 & 0.024 & 0.595 & -0.104 \\
\hline Width & $\begin{array}{l}0.364 \\
(78)\end{array}$ & $\begin{array}{l}0.435 \\
(61)\end{array}$ & $\begin{array}{l}1.000 \\
(81)\end{array}$ & 0.534 & 0.412 & 0.246 & 0.174 \\
\hline Diameter & $\begin{array}{l}0.241 \\
(82)\end{array}$ & $\begin{array}{l}0.256 \\
(65)\end{array}$ & $\begin{array}{l}0.454 \\
(76)\end{array}$ & $\begin{array}{l}1.000 \\
(85)\end{array}$ & 0.459 & 0.234 & 0.340 \\
\hline $\begin{array}{l}\text { Operating } \\
\text { pressure }\end{array}$ & $\begin{array}{l}0.347 \\
(63)\end{array}$ & $\begin{array}{l}0.145 \\
(50)\end{array}$ & $\begin{array}{l}0.360 \\
(62)\end{array}$ & $\begin{array}{l}0.548 \\
(66)\end{array}$ & $\begin{array}{l}1.000 \\
(66)\end{array}$ & 0.013 & 0.534 \\
\hline Burial depth & $\begin{array}{l}0.146 \\
(48)\end{array}$ & $\begin{array}{l}0.804 \\
(37)\end{array}$ & $\begin{array}{l}0.290 \\
(46)\end{array}$ & $\begin{array}{l}0.192 \\
(50)\end{array}$ & $\begin{array}{l}0.082 \\
(43)\end{array}$ & $\begin{array}{l}1.000 \\
(50)\end{array}$ & -0.003 \\
\hline $\begin{array}{l}\text { Length of } \\
\text { rupture }\end{array}$ & $\begin{array}{l}0.917 \\
(44)\end{array}$ & $\begin{array}{l}-0.155 \\
(36) \\
\end{array}$ & $\begin{array}{l}-0.029 \\
(41) \\
\end{array}$ & $\begin{array}{l}0.203 \\
(43)\end{array}$ & $\begin{array}{l}0.317 \\
(42)\end{array}$ & $\begin{array}{l}-0.013 \\
(32)\end{array}$ & $\begin{array}{l}1.000 \\
(45)\end{array}$ \\
\hline
\end{tabular}

\section{Crater length $\left(C_{l}\right)$}

The result of the crater length depicted in Table 2 suggests with $r$ close to $0.92(\rho=0.65)$ that there is a high correlation between the crater length and the length of rupture. This result reaffirms the claim that this parameter of the pipeline defines the limits of the crater in the longitudinal direction. Therefore, the relationship between these two variables can be expressed as follows:

$\mathrm{C}_{l}=k_{1} \cdot L_{r}$ 
where $k_{1}$ is a linear coefficient. Based on the available data of both variables under a least square approach, it was obtained that $k_{1}=1.15$ [Std. Error $=0.06$ ] with a 95\% CI [1.03, $1.27]$, the RSE is 11.96 , and the adjusted $R^{2}$ is 0.89 . This correlation factor is similar to the 1.02 reported by Bartenev et al. (1996). Although the value of $k_{1}$ calculated here does not conform to some of the values quoted in Table A.1 (e.g., ID 53, 70 and 86), this inaccuracy could be explained by the fact that the expression of proportionality found does not take into account the relevant design parameters of the pipeline such as the density of the soil and the operating pressure, which is the driving force of the process.

\section{Crater depth $\left(C_{d}\right)$}

Regarding the crater depth, from Table 2 it can be deduced that the parameter with which this variable has a high correlation is the installation depth of the pipeline $(r=0.804, \rho=$ 0.595). This result can be explained by the fact that as the depth of the pipeline increases, so does the confinement effect and, therefore, also increase the amount of ground material that can be expelled by the energy of the gas released. In other words, as the burial depth is increased, the crater depth also increases until a maximum is reached (Cooper, 1996).

According to the data analysed, the underlying depth at which the most probable maximum sizes of the crater can occur is between 0.9 and $9 \mathrm{~m}$.

The relationship between these two variables can be expressed as the Eq. (2). In this case, the mean linear coefficient is $k_{2}=1.90$ [Std. Error $=0.12$ ] with a 95\% CI [1.65, 2.14], the $\mathrm{RSE}$ is 1.65 and the adjusted $R^{2}$ is 0.89 . As in the previous case, there is also no perfect match of $k_{2}$ with some of the values listed in Table A.1 (e.g., ID 8, 11 and 31); however, it should be noted that the inclusion of important variables such as soil density, operating pressure, and pipe diameter could contribute to improving the prediction of crater depth.

$\mathrm{C}_{d}=k_{2} \cdot B_{d}$

\section{Crater width $\left(C_{w}\right)$}

Regarding the crater width, the pipeline parameter with which it presents the "highest" correlation is with the diameter (Table 2). This appreciation coincides with the result found by Silva et al. (2016), who point out that the crater width increases based on the pipeline diameter. However, since in this case, the correlation coefficient is relatively low $(r=$ 0.454, $\rho=0.534$ ), no precise conclusions can be drawn about the influence of this parameter on the crater width using linear correlation factors. However, a possible influence can be drawn using a monotonic transformation like a logarithmic regression. The following expression was obtained for the crater width in this case including an intercept:

$\mathrm{C}_{w}=k_{3} \cdot D^{\alpha}$

where $k_{3}$ and $\alpha$ are regression coefficients associated with the intercept and the diameter, respectively. For the gathered records, it was obtained that $k_{3}=0.53$ [Std. Error $=0.39$ ] with $95 \%$ CI $[0.24,1.14], \alpha=0.90$ [Std. Error $=0.13]$ with a 95\% CI $[0.65,1.14]$. For this case, the RSE is 0.47 and the adjusted $R^{2}$ is 0.42 .

\subsection{Multivariate regression of the crater dimensions}


Despite the results drawn with linear or power law regressions with one variable, the crater dimensions would be more accurately described based on the pipeline parameters using a multivariate approach. For this purpose, logarithmic regressions were considered because some features, such as the rupture length, had wider ranges (i.e., greater than 10:1). Also, logarithmic regressions would help to stabilize the variance and nonlinear performances. If $Y$ denotes the response and $X$ the variables evaluated, the logarithmic regression would have the general form of Eq. 4. Here $\beta_{0}$ is the intercept, $\beta_{i}$ are the regression coefficients obtained from a least squares approach and $\epsilon$ is the associated error.

$\log Y=\beta_{0}+\sum_{i} \beta_{i} \log X_{i}+\epsilon$

A variable selection approach was used to perform the multivariate regression based on the Best Subset Selection approach described by James et al. (2013). This selection fits separate least square regressions for each combination of independent variables (or predictor), then all the regressions are compared to identify the best one for a given number of predictors. For this purpose, the R-project function regsubsets was implemented (James et al., 2013).

Once the best predictors are selected, the best regressions were obtained based on the minimum RSE, maximum adjusted $R^{2}$, and modified versions of the Akaike Information Criteria (AIC) and the Bayesian Information Criteria (BIC) previously used by AmayaGómez et al. (2018). In what follows, the best regressions are described in more detail, which in all cases omit the intercept in Eq. 4. In addition, the regression assumptions are evaluated using their diagnostic plots, i.e., the residuals vs. fitted values, the quantilequantile $(q-q)$ plot, and the regression leverage, i.e., observation with unusual value in the independent variables (i.e., predictor). Also, an outlier diagnosis was implemented to evaluate if any register should be removed. Therefore, the studentized residuals were considered to identify possible outliers, which corresponds with the residual errors divided by their standard error. According to James et al. (2013), the observations whose studentized residuals are greater than 3 (absolutely) are possible outliers.

\section{Crater length $\left(C_{l}\right)$}

The Best Subset selection established that the predictors that better describe the crater length were the rupture length and the pipeline diameter. The following regression was obtained:

$\mathrm{C}_{l}=L_{r}^{\beta_{1}} \cdot D^{\beta_{2}}$

where $\beta_{1}$ is 0.37 [Std. Error 0.07] with a 95\% CI [0.22, 0.52], $\beta_{2}$ is 0.71 [Std. Error 0.06] with a $95 \%$ CI $[0.59,0.83]$, the RSE is 0.46 , and the adjusted $R^{2}$ is 0.98 . The logarithmic multivariate regression decreases the RSE significantly (from 11.96 to 0.46 ) and increases slightly the adjusted $R^{2}$.

Regarding the regression assumptions, Fig. 7a indicates that some records affect the pattern of the red line, but overall it has a flat tendency confirming the linearity assumption. Fig. $7 \mathrm{~b}$ illustrates that the majority of residuals lie in the diagonal, which overall satisfies the 
normality assumption. Fig. 7c shows a moderate dispersion, which suggests that the independence assumption could be satisfied, but in general, more records are required. Finally, the regression presents low leverage as can be noted in Fig. $7 \mathrm{~d}$ and the absolute studentized residual is less than 3 , which indicate that there is not substantial evidence for the presence of outliers. Based on the aforementioned, the regression assumptions are overall satisfied.

\section{Crater depth $\left(C_{d}\right)$}

According to the results of the Best Subset, the variables with a better prediction of the crater depth were the rupture length, the burial depth, and the pipeline diameter, obtaining the following expression:

$\mathrm{C}_{d}=L_{r}^{\beta_{3}} \cdot B_{d}^{\beta_{4}} \cdot D^{\beta_{5}}$

where $\beta_{3}$ is -0.14 [Std. Error 0.07] with a 95\% CI [-0.29, 0.016], $\beta_{4}$ is 0.27 [Std. Error 0.14 ] with a $95 \%$ CI [-0.016, 0.55], $\beta_{5}$ is 0.48 [Std. Error 0.07] with a $95 \%$ CI [0.33, 0.63], the RSE is 0.36 , and the adjusted $R^{2}$ is 0.93 .

The diagnostic plots for this regression shown in Fig8 indicate that the linearity assumption is satisfied except for a couple of records (Fig. 8a), that the residuals follow a normal distribution (Fig. 8b), and that the residuals are mostly equally spread (Fig. 8c). This last result suggests that the variance does not change drastically along the fitted values and the data are independent. Finally, there is not significant leverage (less than 0.4), and the studentized diagnosis lies within -2.16 and 1.60, so there is not strong evidence about outliers, which in turn, confirm the regression assumptions.

\section{Crater width $\left(C_{w}\right)$}

For the crater width, the Best Subset selection identifies the pipeline diameter and the burial depth as the parameter that better predicts this crater dimension. The following expression was then obtained:

$$
\mathrm{C}_{w}=D^{\beta_{6}} \cdot B_{d}^{\beta_{7}}
$$

where $\beta_{6}$ is 0.71 [Std. Error 0.028] with a $95 \%$ CI [0.65, 0.77], $\beta_{7}$ is 0.20 [Std. Error 0.14] with a $95 \%$ CI [-0.085, 0.49], the RSE is 0.44 , and the adjusted $R^{2}$ is 0.97 .

Despite some records have a slight high residual from the regression predictions, the diagnostic plot in Fig. 9 confirm the regression assumptions regarding the linearity (red line almost flat), the normality of the residuals, independence and homoscedasticity. Also, Fig. $9 \mathrm{~d}$ shows low leverage, and the studentized lied in the range from -2.43 to 2.68 , which indicate that there is not enough evidence for outliers.

\subsection{Conditional probabilities}

The different accidental sequence can follow after the release of NG from a pipeline. For instance, depending on if an immediate or delayed ignition takes place, a jet fire, flash fire or a vapour cloud explosion (VCE) may occur. Detailed event trees have been developed 
to provide the conditional probabilities of occurrence of the final events after the rupture of a pipeline and the formation of a crater, as well as of the domino effect.

\section{Final outcomes}

From the event tree set up for these accidents as shown in Fig. 10, it can be seen that the immediate ignition is not very likely, showing a probability of 0.344. Bubbico et al. (2016) provide an average value of 0.341 for the immediate ignition probability of compressed gases (with the weights being the fraction of cases of catastrophic and full-bore ruptures releases), which matches the value just found correctly.

For releases when the cloud dispersion is almost certain (50 cases out of 90 characterized by the "no immediate ignition" option), a median delayed ignition probability of $50 \%$ is observed; furthermore, the probability of flame front acceleration is higher (80\%). In contrast to the case of the immediate ignition probability, the obtained probabilities for delayed ignition and explosion based on the reported data are higher than those cited by Bubbico et al. (2016); that is, 0.464 for delayed ignition and 0.641 for flame front acceleration.

Table 3 reports the overall probabilities of occurrence of the possible final events after the release of NG. It must be observed that since some of the final events can happen simultaneously, the probabilities can amount to more than 1.

Table 3

Overall probabilities for each type of final event.

\begin{tabular}{ll}
\hline Final event & Overall probability \\
\hline Jet fire & 0.544 \\
Fireball & 0.100 \\
Flash fire & 0.055 \\
Vapour Cloud Explosion & 0.223 \\
Dispersion & 0.278 \\
\hline
\end{tabular}

According to Table 3, in little less than a third of all the cases (specifically $27.8 \%$ ), there were no dangerous consequences. Among the dangerous events, the jet fire is the most likely scenario (54.4\% of occurrence), compared to $22.3 \%$ of a VCE or a $10 \%$ of a fireball, deriving either from an immediate ignition of the release, or generated by another preceding dangerous event like a flash fire or a VCE.

\section{Domino effect sequences}

Of the 90 accidents that involved the formation of a crater, in 31 of these accidents there was at least a second pipeline parallel to the failed pipeline. From these events, the probability of domino effect by the formation of a crater in parallel pipelines was estimated. The results are shown in the event tree of Fig. 11; this results should be taken with caution, as the number of cases is certainly reduced.

According to Fig. 11, there is a high probability (0.806) that a second parallel pipeline does not fall within the limits of the crater after the initial rupture, i.e., that it is not affected either by the explosive effect or by the thermal radiation in case of fire. From the cases 
within the crater limits, none of them failed for the explosive rupture of the first pipeline, which indicates that the probability that the exposed pipeline would be affected by the explosive rupture is negligible. This figure also illustrates that in all the cases in which a secondary pipeline was exposed, the gas releasing from the source pipe was ignited. From the six cases exposing a secondary pipeline, only one of them present a flame impingement at the second pipe, which would imply a conditional probability of 0.167 , and a failure due to thermal impact. If the flames do not impinge directly on the exposed pipeline, the probability of failure would be close to 0.2 if it receives strong thermal radiation. The overall probability that a second pipe located inside the crater will fail due to the thermal impact of the first ruptured pipe is low. No significant conclusions can be drawn from the statistical point of view at the moment. However, the possibility of occurrence of a domino accident should not be ignored. Table 4 summarizes the information of the identified crater accidents that involved a domino effect in parallel pipelines.

Table 4

Crater accidents with a domino effect in parallel NG pipelines.

\begin{tabular}{|c|c|c|c|c|}
\hline \multirow{2}{*}{$\begin{array}{l}\text { Date } \\
\text { Place }\end{array}$} & Pipeline 1 & Pipeline 2 & \multirow[t]{2}{*}{ System configuration } & \multirow[t]{2}{*}{ Crater configuration } \\
\hline & \multicolumn{2}{|c|}{$\begin{array}{l}\text { Diameter / Burial depth / } \\
\text { Pressure / Rupture length }\end{array}$} & & \\
\hline $\begin{array}{l}\text { 29/07/1995 } \\
\text { Rapid City, } \\
\text { MB, Canada } \\
\text { (TSB, 1997; } \\
\text { HSE, 2000) }\end{array}$ & $\begin{array}{l}\text { 42-in / } 1.5 \mathrm{~m} \\
\text { / } 60.7 \mathrm{bar} / \\
10.5 \mathrm{~m}\end{array}$ & $\begin{array}{l}36-\mathrm{in} / 1.5 \mathrm{~m} \\
/ 60.7 \mathrm{bar} / \\
8.5 \mathrm{~m}\end{array}$ & Ground level $\nabla$ & \\
\hline $\begin{array}{l}\text { 28/06/2012 } \\
\text { Buick, BC, } \\
\text { Canada } \\
\text { (TSB, 2013a) }\end{array}$ & $\begin{array}{l}\text { 16-in / - / } \\
66.6 \text { bar / } 17 \\
\mathrm{~m}\end{array}$ & $\begin{array}{l}6.62-\mathrm{in} / \text { - / } \\
8.7 \mathrm{bar} / \\
0.45 \mathrm{~m}\end{array}$ & $\begin{array}{l}\text { Ground level } \\
-3 \mathrm{~m} \rightarrow \underset{\uparrow}{0.5 \mathrm{~m}}\end{array}$ & \\
\hline
\end{tabular}

In the accident in Rapid City, Canada (1995), one of the six NG pipelines that make up the system failed. The ruptured occurred in the 42 -in $(1067 \mathrm{~mm})$ gas pipeline as a result of stress corrosion cracking. The explosive event created a crater of $51 \mathrm{~m}$ length, $23 \mathrm{~m}$ wide and $5 \mathrm{~m}$ deep, which left exposed the 36-in $(914 \mathrm{~mm})$ pipeline installed at the same depth, but a $7 \mathrm{~m}$ distance (less than the company`s horizontal spacing standard). The heat overload, produced by the fire of the gas releasing from the first pipeline, caused the rupture and ignition of the 36-in $(914 \mathrm{~mm})$ pipeline. A third 48-in $(1220 \mathrm{~mm})$ pipeline, passing under the location of the first and second pipeline ruptures, was exposed to the fire but did not fail. The remaining three pipelines were not affected, as they did not fall within the crater limits. One person was injured, and the fire consumed 19,600 $\mathrm{m}^{3}$ of NG.

In the accident near Buick, Canada (2012), a rupture and ignition occurred on a 16-in (406 $\mathrm{mm}$ ) gas pipeline due to a pre-existing hook crack. Prior to the rupture, this pipeline experienced a gradual pressure increase due to the accumulating gas when the system was temporarily shut down. The elevated pressure was sufficient to rupture the pipe along the longitudinal seam starting at the location of the pre-existing hook crack. A large crater was 
created (17 $\mathrm{m}$ long, $7.6 \mathrm{~m}$ wide and $1.1 \mathrm{~m}$ deep) that exposed the 6.62-in (168 mm) gas pipeline located nearby in the same right-of-way, but without damaging it. Approximately 25 minutes later, this pipeline, which had also been shut down, ruptured as a result of overheating due to fire impingement, and the escaping gas also ignited contributing to feeding the fire. At the time of the ruptures, both pipelines contained pressurized sour gas. The fire consumed $961,400 \mathrm{~m}^{3}$ of $\mathrm{NG}$, and 1.6 hectares of land were burned.

Based on the information from both accidents, the regressions from Eq. (1) to Eq. (3) for the univariate approach, and Eq. (5) to Eq. (7) for the multivariate approach, preliminary predictions of the crater dimensions were estimated (Table 5). Note that the burial depth of the pipelines in the Buick accident was not reported, so for comparison purposes, they are assumed as a cover of $3 \mathrm{ft}$. $(0.91 \mathrm{~m})$, which is commonly implemented (ASME, 2002). The preliminary predictions show interesting results of the crater width and depth, bearing in mind that the reported dimensions account the effects from the two failures, whereas these predictions consider them separately. For more in-depth analyses of these accidents, please refer to the approach proposed in Amaya-Gómez et al. (2018). The records and correlation factors proposed in this paper can be used to identify preliminary domino effect scenarios based on some safety distances. For these cases, a rupture centered at P1 would uncover P2 because the half of predicted width is greater than the separation between the two pipelines (i.e., $12.77 \mathrm{~m}$ for Rapid City and 5.01 for Buick accidents).

\section{Table 5}

Comparisons of the predicted confidence intervals of the craters for the domino effect cases for the univariate and multivariate regressions.

\begin{tabular}{|c|c|c|c|c|c|c|c|c|c|c|}
\hline \multirow{2}{*}{ Event } & \multirow{2}{*}{ Pipe } & \multirow{2}{*}{$\begin{array}{l}D \\
\text { (in) }\end{array}$} & \multirow{2}{*}{$\begin{array}{l}B_{d} \\
(\mathrm{~m})\end{array}$} & \multirow{2}{*}{$\begin{array}{l}L_{r} \\
(\mathrm{~m})\end{array}$} & \multicolumn{3}{|c|}{ Univariate prediction } & \multicolumn{3}{|c|}{ Multivariate prediction } \\
\hline & & & & & $\mathrm{C}_{l}(\mathrm{~m})$ & $\mathrm{C}_{d}(\mathrm{~m})$ & $\mathrm{C}_{w}(\mathrm{~m})$ & $\mathrm{C}_{l}(\mathrm{~m})$ & $\mathrm{C}_{d}(\mathrm{~m})$ & $\mathrm{C}_{w}(\mathrm{~m})$ \\
\hline $\begin{array}{l}\text { Rapid } \\
\text { City*** }\end{array}$ & P1 & 42 & 1.5 & 10.5 & $\begin{array}{l}(10.82- \\
13.37)\end{array}$ & $\begin{array}{l}(2.48- \\
3.20)\end{array}$ & $\begin{array}{l}(27.86- \\
30.73)\end{array}$ & $\begin{array}{l}(28.05- \\
41.61)\end{array}$ & $\begin{array}{l}(3.99- \\
6.01)\end{array}$ & $\begin{array}{l}(12.68- \\
18.59)\end{array}$ \\
\hline \multirow{3}{*}{ Buick*** } & $\mathrm{P} 2$ & 36 & 1.5 & 8.5 & $\begin{array}{l}(8.76- \\
10.82)\end{array}$ & $\begin{array}{l}(2.48- \\
3.20)\end{array}$ & $\begin{array}{l}(23.89- \\
26.34)\end{array}$ & $\begin{array}{l}(23.32- \\
34.37)\end{array}$ & $\begin{array}{l}(3.81- \\
5.74)\end{array}$ & $\begin{array}{l}(11.46- \\
16.54)\end{array}$ \\
\hline & P1 & 16 & $0.91^{*}$ & 17 & $\begin{array}{l}(17.52- \\
21.65)\end{array}$ & $\begin{array}{l}(1.51- \\
1.95)\end{array}$ & $\begin{array}{l}(10.61- \\
11.70)\end{array}$ & $\begin{array}{l}(17.01- \\
24.80)\end{array}$ & $\begin{array}{l}(2.09- \\
3.02)\end{array}$ & $\begin{array}{l}(5.88- \\
8.36)\end{array}$ \\
\hline & $\mathrm{P} 2$ & 6.62 & $0.91^{*}$ & 0.45 & $\begin{array}{l}(0.46- \\
0.57)\end{array}$ & $\begin{array}{l}(1.51- \\
1.95)\end{array}$ & $\begin{array}{l}(4.39- \\
4.85)\end{array}$ & $\begin{array}{l}(2.06- \\
3.98)\end{array}$ & $\begin{array}{l}(1.80- \\
4.10)\end{array}$ & $\begin{array}{l}(3.30- \\
4.25)\end{array}$ \\
\hline
\end{tabular}

*Assumed as $3 \mathrm{ft}$. ** $C_{l}=51 \mathrm{~m}, C_{d}=5 \mathrm{~m}$, and $C_{w}=23 \mathrm{~m}$. *** $C_{l}=17 \mathrm{~m}, C_{d}=1.1 \mathrm{~m}$, and $C_{w}=7.6 \mathrm{~m}$.

Nevertheless, safety distances in domino effect scenarios depend on the escalating effects from the primary system (Alileche et al., 2015), so these separations should consider the minimum distance at which escalating events are avoided. In the case of natural gas, they will be delimited by the extension of the flame envelope (Flash Fire); the flame length and its direction (Jet Fire); or the overpressure associated with the explosion energy (VCE) (Alileche et al., 2015). Therefore, further analyses are required to estimate a safe distance as the approaches reported in Sklavounos and Rigas, 2006 and Mohsin et al. (2014) for Jet Fire scenarios, which are the most probable events.

\section{Conclusions}

Failures of buried pipelines are accompanied by the formation of a crater that may pose risks to the surrounding people and environment. The crater may expose parallel or 
crossing pipelines, which in turn, could trigger a domino effect scenario. Considering the NG increasing relevance in pipelines, a database of 90 real accidents was gathered to study possible prediction parameters for the crater dimensions. The database attempts to reduce this existing gap for the natural gas transport by pipeline. Until now, a complete record of crater accidents occurred in this type of facility has not been found. The data collected serve as a reference and contributes to keeping understanding the hazards and evaluating risks in the transport of natural gas through pipelines.

Despite the limited number of records obtained, linear relationships could be determined for the length, depth, and width of the crater. Also, conditional probabilities were determined once a loss of containment is assumed for buried pipelines, including the possibility of a domino effect scenario. The analyses of the data suggest that most pipes were installed at a depth from 1 to 2 meters (about 52\%); pipelines tended to operate at high pressures (between 50 and 70 bars), and the most likely length of a pipe rupture varied between 1 and 30 meters.

Data analysis allowed us to obtain relationships to describe the influence of the pipeline parameters (which also determine the energy potential of the rupture) on the dimensions of the resulting crater. According to the cases analysed, the length of the crater caused by the rupture of a pipe is linearly proportional to the length of the break by a correlation factor of 1.15. Similarly, the depth of the crater is linearly proportional to the installation depth of the pipe by a correlation factor of 1.89. Regarding the width of the crater, it was found that the diameter of the pipe is the parameter with which it has a more significant correlation; in this case, the correlation factor obtained is 0.68 in a power law expression.

The conditional probabilities of the branches of the post-accident event trees associated with NG have been calculated from historical records; due to the reduced number of cases, these results should be taken with caution. The overall probability of a safe conclusion (but implying a certain environmental impact) for an accidental release is about $30 \%$. A jet fire represents the most dangerous final event, with an occurrence probability close to $55 \%$. Outcomes characterized by large impact areas, such as VCE, fireballs and flash fires, are less likely.

Although the number of domino accidents identified in parallel pipelines has been low, the intuitive hypothesis that the formation of a crater may lead to a domino effect has been quantitatively confirmed. According to the data found in the literature, there is a probability in parallel pipelines of 0.194 that a second pipeline is inside the crater and, therefore, that it is subject to a certain risk of a domino effect. In this case, the probability of a pipeline being affected (i.e., broken) by the thermal load generated by the fire of the initial rupture is 0.064 . While this probability is low, the reader should bear in mind that this analysis does not consider the effect of the soil in the crater predictions (this aspect will be investigated in future studies), so the occurrence of a domino accident should not be ignored.

\section{Future directions}

The results obtained can be beneficial to establish adequate separation distances in the design and construction of parallel pipes. Indeed, the objective is to avoid any damage to other pipes in case the rupture of one of them implies the formation of a crater and, consequently, being able to avoid the domino effect, so interesting approaches like the 
reported by Nessim et al. (2004) can be used to support the design and assessment of onshore NG pipelines.

\section{Nomenclature}

$B_{d} \quad$ Pipeline burial depth, $\mathrm{m}$

$C_{d} \quad$ Predicted crater depth, $\mathrm{m}$

$C_{l} \quad$ Predicted crater length, $\mathrm{m}$

$C_{w} \quad$ Predicted crater width, $\mathrm{m}$

$D \quad$ Pipeline outer diameter, in

$D_{a c} \quad$ Apparent crater diameter

$D_{t c} \quad$ True crater diameter

$H_{a c} \quad$ Apparent depth of the crater

$H_{t c} \quad$ True depth of the crater

$k_{1} \quad$ Length linear regression coefficient

$k_{2} \quad$ Depth linear regression coefficient

$k_{3} \quad$ Width linear regression coefficient associated with the regression intercept

$L_{r} \quad$ Length of rupture of the pipeline, $\mathrm{m}$

$P_{o p} \quad$ Pipeline operating pressure, bar

$R^{2} \quad$ Coefficient of determination

$r \quad$ Pearson Correlation coefficient

$\alpha \quad$ Correlation factor associated with the pipe diameter

$\beta_{i} \quad$ Multivariate regression coefficients

$\Delta H \quad$ Difference between the depth of the true crater and the apparent crater.

$\rho \quad$ Spearman correlation rank

\section{Acknowledgments}

J.G. Ramírez-Camacho thanks the Mexican National Council of Science and Technology (CONACyT) for the Ph.D. scholarship and the Universidad de Los Andes in Bogota for the support given to this research.

R. Amaya-Gómez thanks the National Department of Science, Technology and Innovation of Colombia for the Ph.D. scholarship (COLCIENCIAS Grant No. 727, 2015) and Campus France for the Eiffel Excellence Program (2018).

This research was partially funded by the Spanish Ministry of Economy and Competitiveness (project CTQ2017-85880-R, co-financed with FEDER funds). 


\section{Appendix}

Table A.1

Domino effect in NG pipelines involving the formation of a crater.

\begin{tabular}{|c|c|c|c|c|c|c|c|c|c|c|c|c|c|c|c|}
\hline \multirow[t]{2}{*}{ ID } & \multirow{2}{*}{$\begin{array}{l}\text { Date } \\
\text { Place }\end{array}$} & \multirow[b]{2}{*}{$\begin{array}{l}\text { Diameter (in) / } \\
\text { Thickness (in) / Grade / } \\
\text { Installation year / Type } \\
\text { of pipeline / Pressure } \\
\text { (bar) / Burial depth (m) }\end{array}$} & \multicolumn{5}{|c|}{ Apparent crater dimensions } & \multirow[b]{2}{*}{$\begin{array}{l}\text { Rupture } \\
\text { length (m) / } \\
\text { Distance to } \\
\text { pipe } \\
\text { fragments (m) }\end{array}$} & \multirow[b]{2}{*}{ Ignition } & \multirow{2}{*}{$\begin{array}{l}\text { Flame } \\
\text { height } \\
\text { (m) }\end{array}$} & \multirow{2}{*}{$\begin{array}{l}\text { Time (min) } \\
\text { from release } \\
\text { to ignition / } \\
\text { to shutdown }\end{array}$} & \multirow{2}{*}{\multicolumn{2}{|c|}{$\begin{array}{l}\text { Cause Injuries / } \\
\text { of Deaths / } \\
\text { failure Evacuees }\end{array}$}} & \multirow{2}{*}{ Report } & \multirow[t]{2}{*}{ Sources } \\
\hline & & & $\begin{array}{l}\text { Length } \\
\text { (m) }\end{array}$ & $\begin{array}{l}\text { Width } \\
\text { (m) }\end{array}$ & $\begin{array}{l}\text { Depth } \\
\text { (m) }\end{array}$ & $\begin{array}{l}\text { Area }^{(a)} \\
\left(\mathrm{m}^{2}\right)\end{array}$ & $\begin{array}{l}\text { Volume }^{(\mathbf{b})} \\
\left(\mathrm{m}^{3}\right)\end{array}$ & & & & & & & & \\
\hline 1 & $\begin{array}{l}\text { 17/01/1954 } \\
\text { Toledo, OH, USA }\end{array}$ & $16 /-/-/-/ \mathrm{T} / 27.6 /-$ & 18.3 & 2.4 & 3 & 35 & 276 & $-1-$ & No & None & $-/ 30$ & $\mathrm{MF}$ & $0 / 0 /-$ & - & $\begin{array}{l}\text { Toledo } \\
\text { Blade, } 1954\end{array}$ \\
\hline 2 & $\begin{array}{l}\text { 18/06/1961 } \\
\text { Laurel, MS, USA }\end{array}$ & $36 /-/-/-/ \mathrm{T} /-/-$ & 9.1 & 9.1 & 6.1 & 65 & 1060 & $-/ 183$ & Yes & - & $-1-$ & - & $10 / 0 /-$ & - & $\begin{array}{l}\text { Evening } \\
\text { Independent, } \\
1961\end{array}$ \\
\hline 3 & $\begin{array}{l}\text { 19/11/1961 } \\
\text { Warrenton, VA, USA }\end{array}$ & $-1-1-1-1-1-1-$ & 12 & 3 & 1.8 & 28 & 136 & $12 / 137$ & Yes & - & $-1-$ & - & $0 / 0 /-$ & - & $\begin{array}{l}\text { St. Joseph } \\
\text { Gazette, } \\
1961\end{array}$ \\
\hline 4 & $\begin{array}{l}\text { 04/03/1965 } \\
\text { Natchitoches, LA, } \\
\text { USA }\end{array}$ & $\begin{array}{l}24 / 0.25 / \mathrm{X} 46 / \text { - / - / } \\
54.6 / 1\end{array}$ & 23 & 9 & 4.5 & 163 & 1950 & $8.2 / 107$ & Yes & - & $\begin{array}{l}\text { Immediate / } \\
45-60\end{array}$ & $\mathrm{C}$ & $17 / 9 /-$ & - & $\begin{array}{l}\text { HSE, 2002; } \\
\text { MHIDAS, } \\
2007\end{array}$ \\
\hline 5 & $\begin{array}{l}\text { 22/02/1973 } \\
\text { Austin, TX, USA }\end{array}$ & $\begin{array}{l}10.8 / 0.373 /-/ \text { - / - / } \\
36.9 / 1\end{array}$ & 3.05 & 3.05 & - & 7.3 & - & $\begin{array}{l}\text { - / No } \\
\text { fragments }\end{array}$ & Yes & - & $10-15 / 22$ & MF & $2 / 6 /-$ & - & HSE, 2002 \\
\hline 6 & $\begin{array}{l}\text { 02/01/1974 } \\
\text { Illinois, USA }\end{array}$ & $22 /-/-/-/ \mathrm{T} /-/-$ & 18.3 & - & 4.6 & - & - & $-1-$ & Yes & 45 & $-1-$ & - & $-1-1-$ & - & $\begin{array}{l}\text { Star-News, } \\
1974\end{array}$ \\
\hline 7 & $\begin{array}{l}\text { 02/03/1974 } \\
\text { Monroe, LA, USA }\end{array}$ & $\begin{array}{l}30 / 0.438 / \mathrm{X} 52 /-/ \mathrm{T} / \\
56 / 1.95\end{array}$ & & 9.1 & 7.6 & 215 & 4346 & $12 /-$ & Yes & - & $\begin{array}{l}\text { Immediate / } \\
85\end{array}$ & MF & $0 / 0 / 0$ & - & HSE, 2002 \\
\hline 8 & $\begin{array}{l}\text { 15/03/1974 } \\
\text { Farmington, NM, } \\
\text { USA }\end{array}$ & $\begin{array}{l}12 / 0.25 /-/ \text { / / T / } 34.9 \\
/ 0.76\end{array}$ & & 5.2 & 3 & 53 & 425 & $2.4 / 30$ & Yes & 100 & $8 / 75$ & $\mathrm{C}$ & $0 / 3 / 0$ & - & HSE, 2002 \\
\hline 9 & $\begin{array}{l}\text { 21/05/1974 } \\
\text { Meridian, MS, USA }\end{array}$ & $\begin{array}{l}6.6 / 0.071 / \text { / / } 1970 / G \\
/ 21.1 / 0.9\end{array}$ & & 3 & 1.8 & 7 & 34 & $\begin{array}{l}- \text { / No } \\
\text { fragments }\end{array}$ & Yes & 100 & $20 /-$ & $\mathrm{C}$ & $0 / 6 /-$ & - & $\begin{array}{l}\text { MHIDAS, } \\
2007\end{array}$ \\
\hline 10 & $\begin{array}{l}\text { 09/06/1974 } \\
\text { Bealeton, VA, USA }\end{array}$ & $\begin{array}{l}30 / 0.312 / \mathrm{X} 52 /-/ \mathrm{T} / \\
50.5 / 1\end{array}$ & & 11 & 2.1 & 310 & 1740 & $17 / 91$ & Yes & - & $\begin{array}{l}\text { Immediate / } \\
55-105\end{array}$ & $\mathrm{C}$ & $0 / 0 / 0$ & - & HSE, 2002 \\
\hline 11 & $\begin{array}{l}\text { 09/08/1976 } \\
\text { Cartwright, LA, USA }\end{array}$ & $\begin{array}{l}20 / 0.25 /-/ 1949 / \mathrm{T} / \\
54.1 / 0.6\end{array}$ & 13.7 & 7.6 & 3.05 & 82 & 665 & $-/-$ & Yes & 60 & $\begin{array}{l}\text { Immediate / } \\
40-60\end{array}$ & TPA & $1 / 6 /-$ & - & HSE, 2002 \\
\hline
\end{tabular}




\begin{tabular}{|c|c|c|c|c|c|c|c|c|c|c|c|c|c|c|}
\hline \multirow{2}{*}{$\begin{array}{l}\text { ID Date } \\
\text { Place }\end{array}$} & \multirow{2}{*}{$\begin{array}{l}\text { Diameter (in) / } \\
\text { Thickness (in) / Grade / } \\
\text { Installation year / Type } \\
\text { of pipeline / Pressure } \\
\text { (bar) / Burial depth (m) }\end{array}$} & \multicolumn{5}{|c|}{ Apparent crater dimensions } & \multirow{2}{*}{$\begin{array}{l}\text { Rupture } \\
\text { length (m) / } \\
\text { Distance to } \\
\text { pipe } \\
\text { fragments (m) }\end{array}$} & \multirow[b]{2}{*}{ Ignition } & \multirow{2}{*}{$\begin{array}{l}\text { Flame } \\
\text { height } \\
(\mathrm{m})\end{array}$} & \multirow{2}{*}{$\begin{array}{l}\text { Time }(\mathrm{min}) \\
\text { from release } \\
\text { to ignition / } \\
\text { to shutdown }\end{array}$} & \multirow{2}{*}{$\begin{array}{l}\text { Cause } \\
\text { of } \\
\text { failure }\end{array}$} & \multirow{2}{*}{$\begin{array}{l}\text { Injuries / } \\
\text { Deaths / } \\
\text { e Evacuees }\end{array}$} & \multirow{2}{*}{ Report } & \multirow[t]{2}{*}{ Sources } \\
\hline & & $\begin{array}{l}\text { Length } \\
\text { (m) }\end{array}$ & $\begin{array}{l}\text { Width } \\
(\mathrm{m})\end{array}$ & $\begin{array}{l}\text { Depth } \\
\text { (m) }\end{array}$ & $\begin{array}{l}\text { Area }^{(\mathbf{a})} \\
\left(\mathrm{m}^{2}\right)\end{array}$ & $\begin{array}{l}\text { Volume }^{(\mathbf{b})} \\
\left(\mathrm{m}^{3}\right)\end{array}$ & & & & & & & & \\
\hline $\begin{array}{ll}2 & 01 / 11 / 1978 \\
& \text { Tabasco, Mexico }\end{array}$ & $21 /-/-/-/ \mathrm{D} /-/-$ & 91.4 & - & 6.1 & - & - & $-1-$ & Yes & - & $-1-$ & MF & $11 / 52 /-$ & & $\begin{array}{l}\text { MHIDAS, } \\
2007\end{array}$ \\
\hline $13 \begin{array}{l}11 / 11 / 1979 \\
\text { Monroe, LA, USA }\end{array}$ & $20 /-/-/-/ \mathrm{T} /-/-$ & 21.3 & 21.3 & 6.1 & 355 & 5796 & $-1-$ & No & None & None / - & - & $\begin{array}{l}0 / 0 / \\
\text { Yes }\end{array}$ & - & $\begin{array}{l}\text { Daily Kent } \\
\text { Stater, } 1979\end{array}$ \\
\hline $14 \begin{array}{l}\text { 04/11/1982 } \\
\text { Hudson, IA, USA }\end{array}$ & $\begin{array}{l}20 / 0.281 / \mathrm{X} 52 /-/ \mathrm{T} / \\
57.7 / 0.9\end{array}$ & 19.5 & 15 & 2.75 & 230 & 1685 & $19.2 / 13.7$ & Yes & 100 & $\begin{array}{l}\text { Immediate / } \\
65\end{array}$ & TPA & $0 / 5 /-$ & $X$ & $\begin{array}{l}\text { BAM, 2009; } \\
\text { HSE, } 2002\end{array}$ \\
\hline $\begin{array}{l}15 \text { 25/03/1984 } \\
\text { Eltersdorf, Germany }\end{array}$ & $\begin{array}{l}28 \text { / } 0.276 \text { / DIN } 2470 \text { / } \\
- \text { / T / } 67.5 \text { / } 1\end{array}$ & 30 & 30 & 6 & 707 & 11310 & $10 /-$ & Yes & 100 & $-1-$ & - & $-1-1-$ & - & HSE, 2000; \\
\hline 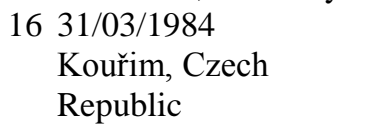 & $-/-/-/-/ \mathrm{D} /-/-$ & 4.6 & 4.6 & - & 17 & - & $-1-$ & - & - & $-/-$ & - & $-1-1-$ & - & $\begin{array}{l}\text { MHIDAS, } \\
2007\end{array}$ \\
\hline $\begin{array}{ll}17 \text { 25/11/1984 } \\
\text { Jackson, LA, USA }\end{array}$ & $\begin{array}{l}30 / 0.311 / \mathrm{X} 52 / 1955 \\
/ \mathrm{T} / 71.4 / 0.9\end{array}$ & 27.5 & 7.6 & 3 & 164 & 1310 & $-1-$ & Yes & 100 & $\begin{array}{l}\text { Immediate / } \\
\text { Immediate }\end{array}$ & TPA & $23 / 5 /-$ & $X$ & HSE, 2002 \\
\hline $\begin{array}{ll}18 & 10 / 03 / 1985 \\
& \text { Ignace, ON, Canada }\end{array}$ & $\begin{array}{l}36 / 0.36 /-/ \text { - / - / } 66.5 \\
/ \text { - }\end{array}$ & 27 & 10.6 & 3 & 225 & 1800 & $22.5 /-$ & Yes & - & $-1-$ & - & $-1-1-$ & - & $\begin{array}{l}\text { HSE, 2002; } \\
\text { BAM, 2009 }\end{array}$ \\
\hline $\begin{array}{l}19 \text { 27/04/1985 } \\
\text { Beaumont, KY, USA }\end{array}$ & $\begin{array}{l}30 \text { / } 0.469 \text { / X65 / } 1952 \\
\text { / T / } 69.7 \text { / } 1.8\end{array}$ & 27.5 & 11.6 & 3.7 & 250 & 2470 & $9 /-$ & Yes & - & $\begin{array}{l}\text { Immediate / } \\
146\end{array}$ & $\mathrm{C}$ & $3 / 5 /-$ & $X$ & HSE, 2000 \\
\hline $\begin{array}{l}20 \text { 20/08/1985 } \\
\text { Lowther, ON, Canada }\end{array}$ & $\begin{array}{l}36 / 0.36 /-/ \text { - / - / } 67.9 \\
/ \text { - }\end{array}$ & 28 & - & 4.9 & - & - & $9.4 / 320$ & Yes & - & $\begin{array}{l}-/ \\
\text { Immediate }\end{array}$ & $\mathrm{C}$ & $-1-1-$ & - & HSE, 2002 \\
\hline $\begin{array}{ll}21 & \text { 21/02/1986 } \\
& \text { Lancaster, KY, USA }\end{array}$ & $\begin{array}{l}30 \text { / } 0.375 \text { / X52 / } 1957 \\
\text { / T / } 69.4 \text { / } 1.8\end{array}$ & 152 & 9.1 & 1.8 & 1085 & 5215 & $146 /-$ & Yes & - & $\begin{array}{l}\text { Immediate / } \\
40\end{array}$ & $\mathrm{C}$ & $8 / 0 / 77$ & $X$ & HSE, 2000 \\
\hline $\begin{array}{l}22 \text { 02/03/1986 } \\
\text { Callander, ON, } \\
\text { Canada }\end{array}$ & $\begin{array}{l}36 / 0.36 /-/ \text { - / - / } 62.6 \\
/ \text { - }\end{array}$ & 31 & - & 4 & - & - & $31 / 185$ & No & None & None / - & - & $-1-1-$ & - & HSE, 2002 \\
\hline $\begin{array}{l}23 \text { 06/06/1990 } \\
\text { Marionville, ON, } \\
\text { Canada }\end{array}$ & $\begin{array}{l}12.7 / 0.252 / 5 \mathrm{LX} / \\
1957 / \text { / / } 47 / 1.2\end{array}$ & 4.6 & 1.5 & 1.7 & 5.5 & 25 & $\begin{array}{l}-/ \text { No } \\
\text { fragments }\end{array}$ & No & None & None / 165 & TPA & $\begin{array}{l}0 / 0 / \\
\text { Yes }\end{array}$ & - & HSE, 2002 \\
\hline $\begin{array}{l}24 \text { 15/01/1991 } \\
\text { Cochrane, ON, } \\
\text { Canada }\end{array}$ & $\begin{array}{l}30 / 0.36 /-/ \text { - / - / } 63.1 \\
/-\end{array}$ & 49 & 33 & 7 & 1270 & 23700 & $25.5 /-$ & No & None & None / 8 & $\mathrm{C}$ & $-1-1-$ & - & HSE, 2002 \\
\hline $\begin{array}{l}25 \text { 08/12/1991 } \\
\text { Cardinal, ON, Canada }\end{array}$ & $\begin{array}{l}20 / 0.252 /-/-/-/ \\
63.4 /-\end{array}$ & 17.8 & 9 & 2.7 & 126 & 906 & $25.7 / 20$ & No & None & None / 35 & $\mathrm{C}$ & $-1-1-$ & - & HSE, 2002 \\
\hline
\end{tabular}




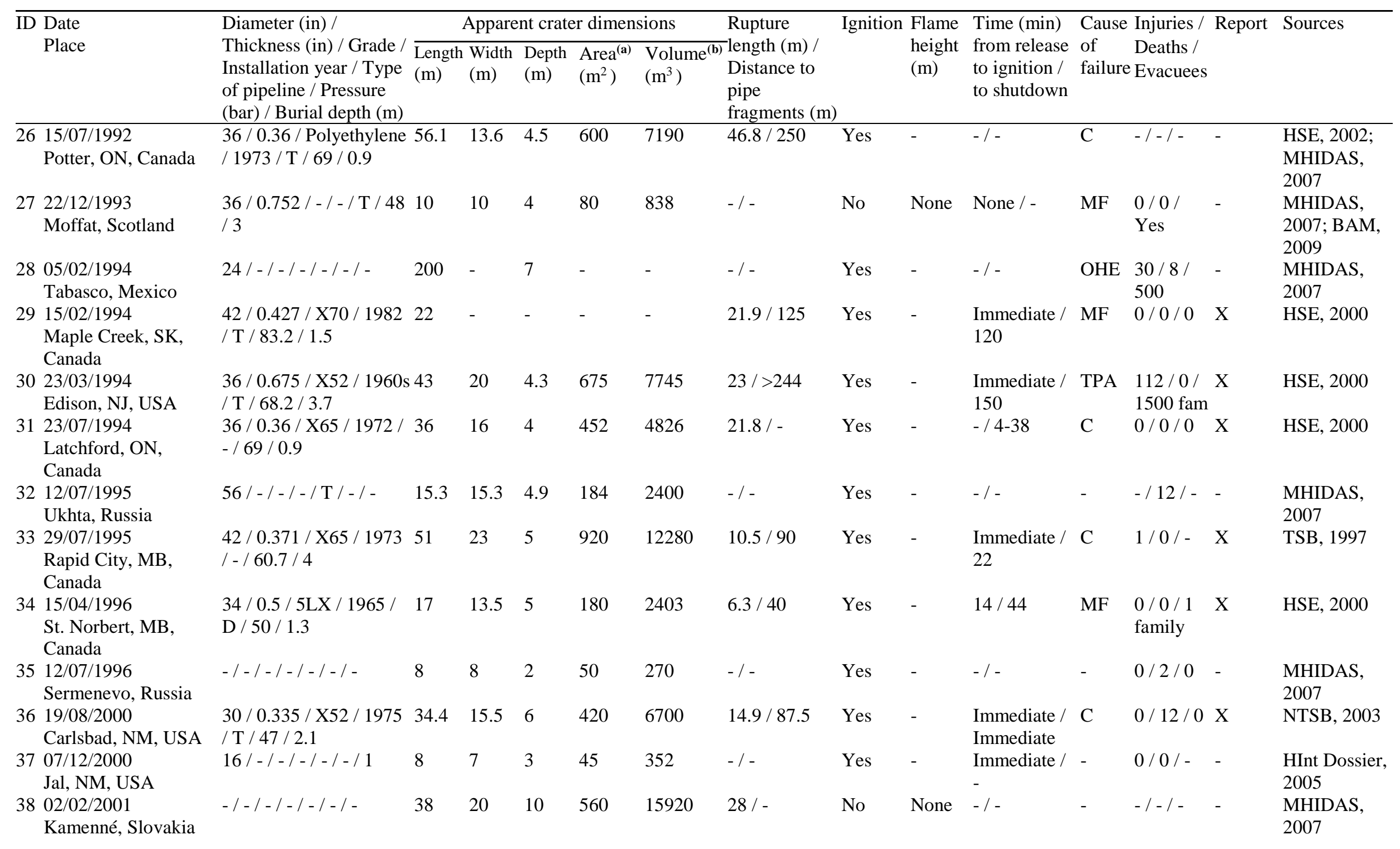




\begin{tabular}{|c|c|c|c|c|c|c|c|c|c|c|c|c|c|c|c|}
\hline \multirow{2}{*}{\multicolumn{2}{|c|}{$\begin{array}{l}\text { ID Date } \\
\text { Place }\end{array}$}} & \multirow{2}{*}{$\begin{array}{l}\text { Diameter (in) / } \\
\text { Thickness (in) / Grade / } \\
\text { Installation year / Type } \\
\text { of pipeline / Pressure } \\
\text { (bar) / Burial depth (m) }\end{array}$} & \multicolumn{5}{|c|}{ Apparent crater dimensions } & \multirow{2}{*}{$\begin{array}{l}\text { Rupture } \\
\text { length (m) / } \\
\text { Distance to } \\
\text { pipe } \\
\text { fragments (m) }\end{array}$} & \multirow{2}{*}{ Ignition } & \multirow{2}{*}{$\begin{array}{l}\text { Flame } \\
\text { height } \\
(\mathrm{m})\end{array}$} & \multirow{2}{*}{$\begin{array}{l}\text { Time (min) } \\
\text { from release } \\
\text { to ignition / } \\
\text { to shutdown }\end{array}$} & \multirow{2}{*}{$\begin{array}{l}\text { Cause } \\
\text { of } \\
\text { failure }\end{array}$} & \multirow{2}{*}{$\begin{array}{l}\text { Injuries / } \\
\text { Deaths / } \\
\text { Evacuees }\end{array}$} & \multirow{2}{*}{ Report } & \multirow[t]{2}{*}{ Sources } \\
\hline & & & $\begin{array}{l}\text { Length } \\
\text { (m) }\end{array}$ & $\begin{array}{l}\text { Width } \\
\text { (m) }\end{array}$ & $\begin{array}{l}\text { Depth } \\
\text { (m) }\end{array}$ & $\begin{array}{l}\text { Area }^{(\mathbf{a})} \\
\left(\mathrm{m}^{2}\right)\end{array}$ & $\begin{array}{l}\text { Volume }^{(\mathbf{b})} \\
\left(\mathrm{m}^{3}\right)\end{array}$ & & & & & & & & \\
\hline 39 & $\begin{array}{l}\text { 22/03/2001 } \\
\text { Weatherford, TX, } \\
\text { USA }\end{array}$ & $12 /-/-/ 1979 /-/-/ 2$ & 5 & 5 & - & 20 & - & $-/-$ & Yes & - & $-1-$ & - & $0 / 0 /-$ & - & $\begin{array}{l}\text { HInt Dossier, } \\
2005\end{array}$ \\
\hline 40 & $\begin{array}{l}15 / 03 / 2002 \\
\text { Iron C., MI, USA }\end{array}$ & $\begin{array}{l}36 \text { / } 0.375 \text { / X65 / } 1968 \\
\text { / T / } 51.7 \text { / } 2\end{array}$ & 36.6 & 9.1 & 9.1 & 262 & 6350 & $24.4 /-$ & No & None & None / - & - & $0 / 0 / 0$ & $\mathrm{X}$ & DOT, 2002 \\
\hline 41 & $\begin{array}{l}11 / 06 / 2002 \\
\text { Easton, CA, USA }\end{array}$ & $16 /-/-/-/-/-/ 1.3$ & 10 & 10 & 6 & 80 & 1260 & $-/-$ & Yes & - & $-/-$ & TPA & $0 / 0 /-$ & - & $\begin{array}{l}\text { HInt Dossier, } \\
2005\end{array}$ \\
\hline 42 & $\begin{array}{l}\text { 30/11/2002 } \\
\text { Brunswick, GA, USA }\end{array}$ & $8 /$ / / - / - / D / $17.2 /$ - & 3 & 3 & 1.5 & 7 & 28 & $-1-$ & No & None & $-1-$ & - & $-1-1-$ & - & $\begin{array}{l}\text { HInt Dossier, } \\
2005\end{array}$ \\
\hline 43 & $\begin{array}{l}\text { 02/02/2003 } \\
\text { near Viola, IL, USA }\end{array}$ & $\begin{array}{l}24 \text { / } 0.312 \text { / X52 / } 1949 \\
\text { / D / } 56 \text { / - }\end{array}$ & - & 12 & 7.6 & - & - & $4.6 / 275$ & Yes & 90 & $-1-$ & - & $\begin{array}{l}0 / 0 / 15 \\
\text { families }\end{array}$ & - & $\begin{array}{l}\text { MHIDAS, } \\
2007 ; \text { BAM, } \\
2009\end{array}$ \\
\hline & $\begin{array}{l}23 / 03 / 2003 \\
\text { Eaton, CO, USA }\end{array}$ & $\begin{array}{l}24 / 0.25 / \mathrm{X} 60 / 1978 / \\
\mathrm{T} / 56 / 3.7\end{array}$ & 30.5 & 15 & 6 & 360 & 5750 & $30.5 /-$ & Yes & - & $-/-$ & - & $\begin{array}{l}0 / 0 / 3 \\
\text { families }\end{array}$ & - & BAM, 2009 \\
\hline 45 & $\begin{array}{l}\text { 01/05/2003 } \\
\text { Pierce C., WA, USA }\end{array}$ & $\begin{array}{l}26 / 0.281 / \text { / / } 1957 / \mathrm{T} \\
/ 43.6 / 1\end{array}$ & 30.5 & 6.1 & 3.7 & 146 & 1442 & $14 / 76.2$ & No & None & None / 90 & $\mathrm{C}$ & $\begin{array}{l}0 / 0 / \\
\text { Hundreds } \\
\text { of homes }\end{array}$ & - & $\begin{array}{l}\text { MHIDAS, } \\
2007\end{array}$ \\
\hline 46 & $\begin{array}{l}13 / 12 / 2003 \\
\text { Toledo, WA, USA }\end{array}$ & $\begin{array}{l}26 / 0.281 /-/ 1957 / \mathrm{T} \\
/ 35 / 1\end{array}$ & - & 15.4 & - & 186 & - & $-1-$ & No & None & None / - & $\mathrm{C}$ & $\begin{array}{l}0 / 0 / 4 \\
\text { families }\end{array}$ & - & $\begin{array}{l}\text { HInt Dossier, } \\
2005\end{array}$ \\
\hline 47 & $\begin{array}{l}\text { 25/03/2004 } \\
\text { Woodward, IA, USA }\end{array}$ & $16 /-/-/-/-/ 55.2 /-$ & 9.1 & 4.6 & - & 33 & - & $-/-$ & Yes & 100 & $-/-$ & TPA & $0 / 0 / 0$ & - & $\begin{array}{l}\text { MHIDAS, } \\
2007\end{array}$ \\
\hline 48 & $\begin{array}{l}\text { 30/07/2004 } \\
\text { Ghislenghien, } \\
\text { Belgium }\end{array}$ & $\begin{array}{l}40 / 0.512 /-/ 1991 / \mathrm{T} \\
/ 80 / 1.1\end{array}$ & 10 & 10 & 4 & 80 & 840 & $-/ 150$ & Yes & - & $45 /-$ & TPA & $132 / 24 /$ & $X$ & BAM, 2009 \\
\hline 49 & $\begin{array}{l}\text { 12/04/2005 } \\
\text { Jefferson, AR, USA }\end{array}$ & $-/-/-/-/ \mathrm{T} /-I-$ & 12 & 6.7 & 0.6 & 63 & 100 & $-/-$ & No & None & $-1-$ & - & $-1-1-$ & - & $\begin{array}{l}\text { MHIDAS, } \\
2007\end{array}$ \\
\hline & $\begin{array}{l}30 / 06 / 2005 \\
\text { Douglas C., KS, USA }\end{array}$ & $\begin{array}{l}20 / 0.312 /-/ 1929 / \mathrm{T} \\
/ 36-47 / 0.6\end{array}$ & 6.1 & 6.1 & - & 30 & - & $4.6 / 45.7$ & No & None & None / 110 & $\mathrm{MF}$ & $0 / 0 / 4$ & $\mathrm{X}$ & $\begin{array}{l}\text { PHMSA, } \\
2012 \mathrm{a}\end{array}$ \\
\hline & $\begin{array}{l}\text { 01/12/2005 } \\
\text { Chicago, IL, USA }\end{array}$ & $20 /-/-/-/ D /-/ 1.8$ & 30.5 & - & 7.5 & - & - & $-/-$ & No & None & None / - & - & $10 / 0 /-$ & - & $\begin{array}{l}\text { Chicago } \\
\text { Tribune, } \\
2005\end{array}$ \\
\hline & $\begin{array}{l}\text { 19/12/2006 } \\
\text { Cass C., MI, USA }\end{array}$ & $\begin{array}{l}24 /-/ \text { - / 1950s / D / } \\
55.2 / 1\end{array}$ & 24.4 & 24.4 & - & 470 & - & $1.2 /-$ & No & None & None / - & TPA & $0 / 1 / 0$ & $X$ & $\begin{array}{l}\text { MIFACE, } \\
2007\end{array}$ \\
\hline
\end{tabular}




\begin{tabular}{|c|c|c|c|c|c|c|c|c|c|c|c|c|c|c|c|}
\hline \multirow{2}{*}{ ID } & \multirow{2}{*}{$\begin{array}{l}\text { Date } \\
\text { Place }\end{array}$} & \multirow[b]{2}{*}{$\begin{array}{l}\text { Diameter (in) / } \\
\text { Thickness (in) / Grade / } \\
\text { Installation year / Type } \\
\text { of pipeline / Pressure } \\
\text { (bar) / Burial depth (m) }\end{array}$} & \multicolumn{5}{|c|}{ Apparent crater dimensions } & \multirow[b]{2}{*}{$\begin{array}{l}\text { Rupture } \\
\text { ) length (m) / } \\
\text { Distance to } \\
\text { pipe } \\
\text { fragments (m) }\end{array}$} & \multirow[b]{2}{*}{ Ignition } & \multirow{2}{*}{$\begin{array}{l}\text { Flame } \\
\text { height } \\
\text { (m) }\end{array}$} & \multirow{2}{*}{$\begin{array}{l}\text { Time }(\mathrm{min}) \\
\text { from release } \\
\text { to ignition / } \\
\text { to shutdown }\end{array}$} & \multirow{2}{*}{$\begin{array}{l}\text { Cause } \\
\text { of } \\
\text { failure }\end{array}$} & \multirow{2}{*}{$\begin{array}{l}\text { Injuries / } \\
\text { Deaths / } \\
\text { Evacuees }\end{array}$} & \multirow{2}{*}{ Report } & \multirow[t]{2}{*}{ Sources } \\
\hline & & & $\begin{array}{l}\text { Length } \\
(\mathrm{m})\end{array}$ & $\begin{array}{l}\text { Width } \\
\text { (m) }\end{array}$ & $\begin{array}{l}\text { Depth } \\
\text { (m) }\end{array}$ & $\begin{array}{l}\text { Area }^{(\mathbf{a})} \\
\left(\mathrm{m}^{2}\right)\end{array}$ & $\begin{array}{l}\text { Volume }^{(\mathbf{b})} \\
\left(\mathrm{m}^{3}\right)\end{array}$ & & & & & & & & \\
\hline 53 & $\begin{array}{l}\text { 12/03/2007 } \\
\text { Württemberg, } \\
\text { Germany }\end{array}$ & $6 /-/-/-/-/ 70 /-$ & 5 & 2 & 2 & 8 & 42 & $-1-$ & Yes & - & $-1-$ & - & $1 /-/-$ & - & BAM, 2009 \\
\hline 54 & $\begin{array}{l}\text { 25/08/2008 } \\
\text { Pilot Grove, MO, } \\
\text { USA }\end{array}$ & $\begin{array}{l}24 \text { / } 0.281 \text { / X48 / } 1937 \\
\text { / T / } 55.2 \text { / } 1.8\end{array}$ & 15.2 & 10 & 2.2 & 120 & 700 & $8.5 / 91.5$ & No & None & None / 39 & $\mathrm{C}$ & $0 / 0 / 0$ & $X$ & DOT, 2008 \\
\hline 55 & $\begin{array}{l}\text { 14/09/2008 } \\
\text { Appomattox, VA, } \\
\text { USA }\end{array}$ & $\begin{array}{l}30 \text { / } 0.344 \text { / X52 / } 1955 \\
\text { / T / } 55.1 \text { / - }\end{array}$ & 23 & 11.3 & 4.6 & 204 & 2504 & $-1-$ & Yes & - & $-1-$ & - & $\begin{array}{l}5 / 0 / 23 \\
\text { families }\end{array}$ & $\mathrm{X}$ & $\begin{array}{l}\text { PHMSA, } \\
2008\end{array}$ \\
\hline 56 & $\begin{array}{l}\text { 01/04/2009 } \\
\text { Căușeni, Moldova }\end{array}$ & $\begin{array}{l}48 /-/ \text { - / 1970s / T / - / } \\
2\end{array}$ & 100 & - & 5 & - & - & $-1-$ & Yes & 50 & $-1-$ & - & $-1-1-$ & - & $\begin{array}{l}\text { European } \\
\text { Commission, } \\
2009\end{array}$ \\
\hline 57 & $\begin{array}{l}\text { 04/05/2009 } \\
\text { Palm City, FL, USA }\end{array}$ & $\begin{array}{l}18 / 0.25 / \mathrm{X} 52 / 1959 / \\
\mathrm{T} / 58.9 / 1.1\end{array}$ & 35.5 & 5.2 & 2.8 & 145 & 1083 & $32.3 / 7.6$ & No & None & None / 120 & $\mathrm{C}$ & $\begin{array}{l}3 / 0 / \\
\text { Yes }\end{array}$ & $X$ & NTSB, 2013 \\
\hline 58 & $\begin{array}{l}\text { 05/05/2009 } \\
\text { Rockville, IN, USA }\end{array}$ & $\begin{array}{l}24 / 0.312 / \mathrm{B} / 1940 / \mathrm{T} \\
/ 54.6 /-\end{array}$ & 18 & 8.5 & - & 120 & - & $-1-$ & Yes & - & $-1-$ & $\mathrm{C}$ & $\begin{array}{l}0 / 0 / 49 \\
\text { families }\end{array}$ & $X$ & DOT, 2009 \\
\hline 59 & $\begin{array}{l}\text { 10/05/2009 } \\
\text { Moscow, Russia }\end{array}$ & $\begin{array}{l}36 /-/ \text { - / } 1976 /-/ \text { / } \\
2.5\end{array}$ & 10.5 & 5 & - & 41 & - & $-1-$ & Yes & 100 & $-1-$ & MF & $\begin{array}{l}5 / 0 / \\
\text { Yes }\end{array}$ & - & $\begin{array}{l}\text { BBC News, } \\
2009\end{array}$ \\
\hline 60 & $\begin{array}{l}\text { 12/09/2009 } \\
\text { Englehart, ON, } \\
\text { Canada }\end{array}$ & $\begin{array}{l}36 \text { / } 0.4 \text { / X65 / } 1973 \text { / - } \\
\text { / } 68.7 \text { / } 0.9\end{array}$ & 6.1 & 6.1 & - & 30 & - & $-/ 150$ & Yes & - & $\begin{array}{l}\text { Immediate / } \\
7\end{array}$ & $\mathrm{C}$ & $\begin{array}{l}0 / 0 / 4 \\
\text { families }\end{array}$ & $X$ & TSB, 2009 \\
\hline 61 & $\begin{array}{l}\text { 05/11/2009 } \\
\text { Bushland, TX, USA }\end{array}$ & $\begin{array}{l}24 / 0.25 / \mathrm{X} 52 / 1948 / \\
\mathrm{T} / 53 / 1.5\end{array}$ & 17.4 & - & 4.3 & 238 & - & $10.7 /$ - & Yes & - & $3 / 50$ & MF & $\begin{array}{l}3 / 0 / \\
200\end{array}$ & $X$ & $\begin{array}{l}\text { PHMSA, } \\
2009\end{array}$ \\
\hline 62 & $\begin{array}{l}\text { 09/09/2010 } \\
\text { San Bruno, CA, USA }\end{array}$ & $\begin{array}{l}30 \text { / } 0.375 / \mathrm{X} 42 \text { / } 1956 \\
/ \mathrm{T} / 25.9 / 0.9\end{array}$ & 21.9 & 7.9 & - & 136 & - & $8.5 / 30.5$ & Yes & - & $\begin{array}{l}\text { Immediate / } \\
95\end{array}$ & OHE & $\begin{array}{l}58 / 8 / \\
300 \text { fam. }\end{array}$ & $\mathrm{X}$ & NTSB, 2011 \\
\hline 63 & $\begin{array}{l}30 / 11 / 2010 \\
\text { Natchitoches Parish, } \\
\text { LA, USA }\end{array}$ & $\begin{array}{l}30 \text { / } 0.312 \text { / X52 / } 1948 \\
/ \mathrm{T} / 46.3 / 1.5\end{array}$ & 4.6 & 4.6 & - & 17 & - & $\begin{array}{l}1.3 / \mathrm{No} \\
\text { fragments }\end{array}$ & No & None & None / 100 & $\mathrm{MF}$ & $\begin{array}{l}0 / 0 / \\
100 \\
\text { families }\end{array}$ & $X$ & $\begin{array}{l}\text { PHMSA, } \\
2011 \mathrm{a}\end{array}$ \\
\hline 64 & $\begin{array}{l}\text { 08/12/2010 } \\
\text { E. Bernard, TX, USA }\end{array}$ & $\begin{array}{l}24 / 0.5 / \text { X40 / } 1947 / \mathrm{T} \\
/ 49.6 / 1\end{array}$ & 30.5 & 7.6 & - & 182 & - & $3.7 / 90$ & No & None & $\begin{array}{l}\text { None / } \\
\text { Immediate }\end{array}$ & $\mathrm{C}$ & $\begin{array}{l}0 / 0 / \\
\text { Yes }\end{array}$ & $X$ & $\begin{array}{l}\text { PHMSA, } \\
2011 b\end{array}$ \\
\hline 65 & $\begin{array}{l}\text { 19/02/2011 } \\
\text { Beardmore, ON, }\end{array}$ & $\begin{array}{l}36 / 0.36 / \text { / / } 1972 \text { / - / } \\
66.2 \text { / } 0.9\end{array}$ & 17 & 13 & - & 173 & - & $9 />100$ & Yes & - & $\begin{array}{l}\text { Immediate / } \\
15\end{array}$ & $\mathrm{C}$ & $0 / 0 / 6$ & $X$ & TSB, 2011 \\
\hline
\end{tabular}




\begin{tabular}{|c|c|c|c|c|c|c|c|c|c|c|c|c|c|c|c|}
\hline \multirow{3}{*}{\multicolumn{2}{|c|}{$\begin{array}{l}\text { ID Date } \\
\text { Place }\end{array}$}} & \multirow[b]{2}{*}{$\begin{array}{l}\text { Diameter (in) / } \\
\text { Thickness (in) / Grade / } \\
\text { Installation year / Type } \\
\text { of pipeline / Pressure } \\
\text { (bar) / Burial depth (m) }\end{array}$} & \multicolumn{5}{|c|}{ Apparent crater dimensions } & \multirow[b]{2}{*}{$\begin{array}{l}\text { Rupture } \\
\text { length (m) / } \\
\text { Distance to } \\
\text { pipe } \\
\text { fragments (m) } \\
\end{array}$} & \multirow[b]{2}{*}{ Ignition } & \multirow{2}{*}{$\begin{array}{l}\text { Flame } \\
\text { height } \\
\text { (m) }\end{array}$} & \multirow{2}{*}{$\begin{array}{l}\text { Time (min) } \\
\text { from release } \\
\text { to ignition / } \\
\text { to shutdown }\end{array}$} & \multirow{2}{*}{$\begin{array}{l}\text { Cause } \\
\text { of } \\
\text { failure }\end{array}$} & \multirow{2}{*}{$\begin{array}{l}\text { Injuries / } \\
\text { Deaths / } \\
\text { Evacuees }\end{array}$} & \multirow{2}{*}{ Report } & \multirow[t]{2}{*}{ Sources } \\
\hline & & & $\begin{array}{l}\text { Length } \\
(\mathrm{m})\end{array}$ & (m) & $\begin{array}{l}\text { Depth } \\
\text { (m) }\end{array}$ & $\begin{array}{l}\text { Area }^{(\mathbf{a})} \\
\left(\mathrm{m}^{2}\right)\end{array}$ & $\begin{array}{l}\text { Volume }{ }^{(\mathbf{b})} \\
\left(\mathrm{m}^{3}\right)\end{array}$ & & & & & & & & \\
\hline & & & & & & & & & & & & & & & \\
\hline 66 & $\begin{array}{l}\text { 20/07/2011 } \\
\text { Gillette, WY, USA }\end{array}$ & $\begin{array}{l}30 \text { / } 0.438 \text { / X70 / } 2010 \\
\text { / T / } 92.4 \text { / } 0.9\end{array}$ & 27 & 7.5 & 2.7 & 160 & 1145 & $25 / 21$ & No & None & None / 85 & $\mathrm{MF}$ & $0 / 0 / 0$ & $\mathrm{X}$ & $\begin{array}{l}\text { PHMSA, } \\
\text { 2012b }\end{array}$ \\
\hline 67 & $\begin{array}{l}\text { 14/11/2011 } \\
\text { Nuevo León, Mexico }\end{array}$ & $36 /-/-/-/ \mathrm{T} /-/-$ & 20 & 20 & 5 & 315 & 4190 & $-1-$ & Yes & 15 & $-1-$ & TPA & $1 / 0 / 0$ & - & $\begin{array}{l}\text { El Universal, } \\
2011\end{array}$ \\
\hline 68 & $\begin{array}{l}\text { 16/11/2011 } \\
\text { Glouster, OH, USA }\end{array}$ & $\begin{array}{l}36 \text { / } 0.344 \text { / X60 / } 1993 \\
\text { / T / } 52.5 \text { / - }\end{array}$ & 9.1 & 9.1 & 4.6 & 65 & 800 & $-1-$ & Yes & - & $-/-$ & MF & $\begin{array}{l}3 / 0 / 3 \\
\text { families }\end{array}$ & $X$ & $\begin{array}{l}\text { PHMSA, } \\
2011 \mathrm{c}\end{array}$ \\
\hline 69 & $\begin{array}{l}\text { 21/11/2011 } \\
\text { Batesville, MS, USA }\end{array}$ & $\begin{array}{l}24 \text { / } 0.25 \text { / X70 / } 1944 \text { / } \\
\mathrm{T} / 51.6 \text { / } 3.7\end{array}$ & 23.8 & 23.8 & 4.6 & 445 & 5457 & $1.4 /-$ & Yes & - & $26 / 30$ & MF & $\begin{array}{l}0 / 0 / 20 \\
\text { families }\end{array}$ & $\mathrm{X}$ & $\begin{array}{l}\text { PHMSA, } \\
2013 \mathrm{a}\end{array}$ \\
\hline 70 & $\begin{array}{l}\text { 03/12/2011 } \\
\text { Marengo C., AL, } \\
\text { USA }\end{array}$ & $\begin{array}{l}36 \text { / - / X60 / } 1964 \text { / G / } \\
54.8 \text { / - }\end{array}$ & 24.2 & 16.8 & 4.3 & 320 & 3661 & $-/ 61$ & Yes & 30 & $\begin{array}{l}\text { Immediate / } \\
17\end{array}$ & - & $0 / 0 / 0$ & $\mathrm{X}$ & $\begin{array}{l}\text { PHMSA, } \\
2011 d\end{array}$ \\
\hline 71 & $\begin{array}{l}\text { 18/01/2012, } \\
\text { Tresana, Italy }\end{array}$ & $30 /-/-/-/-/ 59 /-$ & 20 & 20 & 7 & 315 & 5864 & $-/-$ & Yes & - & $-/-$ & - & $9 / 1 /-$ & - & Kraus, 2014 \\
\hline & $\begin{array}{l}\text { 25/04/2012 } \\
\text { Hinton, IA, USA }\end{array}$ & $24 /-/-/-/-/-/-$ & 30 & 10.7 & 9.2 & 252 & 6185 & $-1-$ & Yes & 90 & $-/-$ & TPA & $2 / 0 /-$ & - & $\begin{array}{l}\text { The Gazette, } \\
2014\end{array}$ \\
\hline & $\begin{array}{l}\text { 06/06/2012 } \\
\text { Laketon, TX, USA }\end{array}$ & $\begin{array}{l}26 \text { / } 0.25 \text { / X52 / } 1957 \text { / } \\
- \text { / } 47.4 \text { / - }\end{array}$ & 18.2 & 5 & - & 72 & - & $15.2 /-$ & Yes & - & Immediate / & - & $0 / 0 / 0$ & $\mathrm{X}$ & $\begin{array}{l}\text { PHMSA, } \\
2012 \mathrm{c}\end{array}$ \\
\hline & $\begin{array}{l}\text { 28/06/2012 } \\
\text { Buick, BC, Canada }\end{array}$ & $\begin{array}{l}16 / 0.25 / X 52 / 1960 / \\
\mathrm{G} / 66.6 / 0.5\end{array}$ & 17 & 7.6 & 1.1 & 102 & 300 & $17 / 20$ & Yes & - & $\begin{array}{l}\text { Immediate / } \\
\text { Previously } \\
\text { shutdown }\end{array}$ & MF & $0 / 0 / 0$ & $\mathrm{X}$ & TSB, 2013a \\
\hline & $\begin{array}{l}11 / 12 / 2012 \\
\text { Sissonville, WV, } \\
\text { USA }\end{array}$ & $\begin{array}{l}20 \text { / } 0.281 / \mathrm{X} 60 \text { / } 1967 \\
\text { / T / } 64.1 \text { / - }\end{array}$ & 22.9 & 10.9 & 4.3 & 195 & 2250 & $11.5 / 12.2$ & Yes & 30 & $\begin{array}{l}\text { Immediate / } \\
>60\end{array}$ & $\mathrm{C}$ & $0 / 0 / 0$ & $X$ & NTSB, 2014 \\
\hline 76 & $\begin{array}{l}\text { 20/08/2013 } \\
\text { Pittsburg C, OK, USA }\end{array}$ & $20 /-I-I-I-I-I-$ & 9.1 & 9.1 & 6.1 & 65 & 1060 & $-1-$ & Yes & - & $-1-$ & - & $0 / 0 / 0$ & - & $\begin{array}{l}\text { NewsOn6, } \\
2013\end{array}$ \\
\hline 77 & $\begin{array}{l}\text { 08/10/2013 } \\
\text { Harper C., OK, USA }\end{array}$ & $\begin{array}{l}30 \text { / } 0.344 \text { / X52 / } 1954 \\
\text { / T / } 55.8 / 1.5\end{array}$ & 67 & 9.1 & 4.6 & 480 & 5874 & $67 /-$ & Yes & 60 & $-/-$ & - & $\begin{array}{l}0 / 0 / \\
\text { Yes }\end{array}$ & $\mathrm{X}$ & $\begin{array}{l}\text { PHMSA, } \\
2013 b\end{array}$ \\
\hline 78 & $\begin{array}{l}\text { 17/10/2013 } \\
\text { Alberta, Canada }\end{array}$ & $\begin{array}{l}36 / 0.465 /-/ 2008 / \mathrm{T} \\
/ 92 /-\end{array}$ & 50 & 15 & 5 & 590 & 7854 & $-/ 130$ & No & None & None / 745 & $\mathrm{MF}$ & $0 / 0 / 0$ & $\mathrm{X}$ & TSB, 2013b \\
\hline & $\begin{array}{l}\text { 29/11/2013 } \\
\text { Houstonia, MO, USA }\end{array}$ & $\begin{array}{l}30 / 0.312 / \text { X60 / } 1962 \\
\text { / T / } 61.6 / 1\end{array}$ & 9.5 & 9.5 & - & 70 & - & $-/ 61$ & Yes & 90 & $-/-$ & $\mathrm{C}$ & $\begin{array}{l}0 / 0 / 3 \\
\text { families }\end{array}$ & - & $\begin{array}{l}\text { PHMSA, } \\
2014 b\end{array}$ \\
\hline
\end{tabular}




\begin{tabular}{|c|c|c|c|c|c|c|c|c|c|c|c|c|c|c|c|}
\hline \multirow{2}{*}{\multicolumn{2}{|c|}{$\begin{array}{l}\text { ID Date } \\
\text { Place }\end{array}$}} & \multirow{2}{*}{$\begin{array}{l}\text { Diameter (in) / } \\
\text { Thickness (in) / Grade / } \\
\text { Installation year / Type } \\
\text { of pipeline / Pressure } \\
\text { (bar) / Burial depth (m) }\end{array}$} & \multicolumn{5}{|c|}{ Apparent crater dimensions } & \multirow{2}{*}{$\begin{array}{l}\text { Rupture } \\
\text { length (m) / } \\
\text { Distance to } \\
\text { pipe } \\
\text { fragments (m) }\end{array}$} & \multirow[b]{2}{*}{ Ignition } & \multirow{2}{*}{$\begin{array}{l}\text { Flame } \\
\text { height } \\
(\mathrm{m})\end{array}$} & \multirow{2}{*}{$\begin{array}{l}\text { Time }(\mathrm{min}) \\
\text { from release } \\
\text { to ignition / } \\
\text { to shutdown }\end{array}$} & \multirow{2}{*}{$\begin{array}{l}\text { Cause } \\
\text { of } \\
\text { failure }\end{array}$} & \multirow{2}{*}{$\begin{array}{l}\text { Injuries / } \\
\text { Deaths / } \\
\text { e Evacuees }\end{array}$} & \multirow{2}{*}{ Report } & \multirow[t]{2}{*}{ Sources } \\
\hline & & & $\begin{array}{l}\text { Length } \\
\text { (m) }\end{array}$ & $\begin{array}{l}\text { Width } \\
\text { (m) }\end{array}$ & $\begin{array}{l}\text { Depth } \\
\text { (m) }\end{array}$ & $\begin{array}{l}\text { Area } \\
\left(m^{2}\right)\end{array}$ & $\begin{array}{l}\text { Volume }^{(\mathbf{b})} \\
\left(\mathrm{m}^{3}\right)\end{array}$ & & & & & & & & \\
\hline 80 & $\begin{array}{l}\text { 25/01/2014 } \\
\text { Otterburne, MB, } \\
\text { Canada }\end{array}$ & $\begin{array}{l}30 / 0.37 / \text { X52 / } 1960 / \\
-/ 63.3 \text { / - }\end{array}$ & 24 & 12.5 & 3 & 236 & 1885 & $14.4 / 100$ & Yes & - & Immediate / & MF & $\begin{array}{l}0 / 0 / 5 \\
\text { families }\end{array}$ & $\mathrm{X}$ & TSB, 2014 \\
\hline 81 & $\begin{array}{l}\text { 13/02/2014 } \\
\text { Adair C., KY, USA }\end{array}$ & $\begin{array}{l}30 \text { / } 0.323 \text { / X65 / } 1965 \\
\text { / T / } 66.3 \text { / } 9.1\end{array}$ & - & 15.2 & 18.3 & 182 & - & $-/ 91$ & Yes & - & $-1-$ & - & $\begin{array}{l}2 / 0 / 23 \\
\text { families }\end{array}$ & - & $\begin{array}{l}\text { PHMSA, } \\
2014 \mathrm{a}\end{array}$ \\
\hline & $\begin{array}{l}\text { 05/04/2014 } \\
\text { Marshall C., WV, } \\
\text { USA }\end{array}$ & $12 /-/-/-/ \mathrm{G} /-/-$ & 3 & 3 & - & 7 & - & $-1-$ & Yes & - & $-1-$ & - & $\begin{array}{l}0 / 0 / \\
\text { Yes }\end{array}$ & - & $\begin{array}{l}\text { The } \\
\text { Intelligencer, } \\
2014\end{array}$ \\
\hline 83 & $\begin{array}{l}\text { 24/04/2014 } \\
\text { France }\end{array}$ & $\begin{array}{l}8.6 /-/ \text { / / } 1976 /-/ 34 / \\
1\end{array}$ & & 4 & 1.5 & 13 & 50 & $-1-$ & No & None & None / - & MF & $-1-1-$ & - & ARIA, 2014 \\
\hline & $\begin{array}{l}\text { 26/05/2014 } \\
\text { Warren, MN, USA }\end{array}$ & $24 /-/$ - / - / T / $56.9 /-$ & 9.1 & 9.1 & 4.6 & 65 & 800 & $-/ 36.6$ & Yes & 30 & $-1-$ & - & $\begin{array}{l}0 / 0 / 10 \\
\text { families }\end{array}$ & - & DRC, 2014 \\
\hline & $\begin{array}{l}\text { 27/06/2014 } \\
\text { E. Godavari, AP, } \\
\text { India }\end{array}$ & $\begin{array}{l}18 \text { / - / X60 / } 2001 / \text { - / } \\
44.1 \text { / } 5\end{array}$ & 7 & 7 & 7 & 39 & 720 & $0.5 /-$ & Yes & $>25$ & $-1-$ & $\mathrm{C}$ & $40 / 18 /-$ & - & $\begin{array}{l}\text { Mishra and } \\
\text { Klaus-Dieter, } \\
2015\end{array}$ \\
\hline 86 & $\begin{array}{l}\text { 23/10/2014 } \\
\text { Ludwigshafen, } \\
\text { Germany }\end{array}$ & $16 /-/-/-/ \mathrm{D} /-/-$ & 10 & 10 & 6 & 80 & 1260 & $-/-$ & Yes & - & $-1-$ & TPA & $\begin{array}{l}11 / 1 / \\
\text { Yes }\end{array}$ & - & $\begin{array}{l}\text { Deutsche } \\
\text { Welle, } 2014\end{array}$ \\
\hline 87 & $\begin{array}{l}\text { 14/01/2015 } \\
\text { Brandon, MS, USA }\end{array}$ & $\begin{array}{l}30 \text { / } 0.375 \text { / X52 / } 1952 \\
\text { / T / } 52.9 \text { / - }\end{array}$ & 9 & 8 & - & 57 & - & $-1-$ & Yes & $>60$ & $-1-$ & MF & $0 / 0 /-$ & $\mathrm{X}$ & $\begin{array}{l}\text { PHMSA, } \\
2015 b\end{array}$ \\
\hline 88 & $\begin{array}{l}\text { 29/01/2015 } \\
\text { Bowling Green, MO, } \\
\text { USA }\end{array}$ & $42 /-/$ - / $2008 / \mathrm{T} /-$ / - & 6.1 & 6.1 & - & 30 & - & $-1-$ & No & None & None / - & MF & $\begin{array}{l}0 / 0 / 50 \\
\text { families }\end{array}$ & - & $\begin{array}{l}\text { The People's } \\
\text { Tribune, } \\
2015\end{array}$ \\
\hline 89 & $\begin{array}{l}17 / 04 / 2015 \\
\text { Fresno, CA, USA }\end{array}$ & $\begin{array}{l}12 \text { / } 0.254 \text { / X42 / } 1962 \\
\text { / D / - / } 1.1\end{array}$ & 6.1 & 5.6 & 2.2 & 27 & 157 & $0.8 / 6$ & Yes & 45 & Immediate / & TPA & $13 / 1 /-$ & $\mathrm{X}$ & $\begin{array}{l}\text { Exponent, } \\
2015\end{array}$ \\
\hline & $\begin{array}{l}\text { 03/08/2015 } \\
\text { Falfurrias, TX, USA }\end{array}$ & $\begin{array}{l}16 \text { / } 0.25 \text { / X42 / } 1947 \text { / } \\
- \text { / } 57 \text { / - }\end{array}$ & 21.3 & 9.1 & - & 152 & - & $16.8 /-$ & No & None & None / - & $\mathrm{C}$ & $\begin{array}{l}2 / 0 / \\
\text { Yes }\end{array}$ & $X$ & $\begin{array}{l}\text { PHMSA, } \\
2015 \mathrm{c}\end{array}$ \\
\hline
\end{tabular}

Type of pipeline $=$ T: Transmission, D: Distribution, G: Gathering.

Cause of failure $=\mathrm{C}$ : Corrosion, MF: Mechanical failure, OHE: Operational/human error, TPA: Third party activity.

(a), (b) These values were computed representing the shape of the crater as a semi-ellipsoid with centre at the origin of coordinates and axes coincident with the Cartesian axes. 


\section{References}

Acton, M. R., Jackson, N. W., Jager, E. E., 2010. Development of Guidelines for Parallel pipelines. In 2010 8th International Pipeline Conference, 485-495. ASME. Canada.

Amaya-Gómez, R., Ramírez-Camacho, J., Pastor, E., Casal, J., Muñoz, F., 2018. Crater formation by the rupture of underground natural gas pipelines: A probabilisticbased model. J. Nat. Gas Sci. Eng. 54, 224-239.

Ambrosini, R. D., Luccioni, B. M., Danesi, R. F., Riera, J. D., Rocha, M. M., 2002. Size of craters produced by explosive charges on or above the ground surface. Shock Waves 12, 69-78. http://dx.doi.org/10.1007/s00193-002-0136-3.

Ambrosini, R. D., Luccioni, B. M., 2006. Craters produced by explosions on the soil surface. J. Appl. Mech. 73 (6), 890-900. http://dx.doi.org/10.1115/1.2173283.

Andrews, R. M., Millwood, N. A., Batte, A., Lowesmith, B. J., 2004. The fracture arrest behaviour of $914 \mathrm{~mm}$ diameter X100 grade steel pipelines. In ASME Proceedings of the 5th International Pipeline Conference, 1693-701. Alberta, Canada.

Alileche, N., Cozzani, V., Reniers, G., Estel, L., 2015. Thresholds for domino effects and safety distances in the process industry: a review of approaches and regulations. Reliab. Eng. Syst. Saf. 143, 74-84.

ARIA, Analysis, Research and Information on Accidents, 2014. French Ministry of Ecology, Sustainable Development and Energy. Report N ${ }^{\circ} 25217$. France.

ARIA, Analysis, Research and Information on Accidents, 2015. French Ministry of Ecology, sustainable development and energy. In www.aria.developpementdurable.gouv.fr (Last accessed: February 29, 2016). France.

ASME, American Society of Mechanical Engineers, 2002. ASME B31.4-2002: Pipeline Transportation Systems for Liquid Hydrocarbons and Other Liquids. Technical Report American Society of Mechanical Engineers New York 41.

BAM, Federal Institute for Materials Research and Testing, 2009. Research Report 289: On the risks of transporting liquid and gaseous fuels in pipelines Research report. Berlin, Germany.

Bartenev, A. M., Gelfand, B. E., Makhviladze, G. M., Roberts, J. P., 1996. Statistical analysis of accidents on the Middle Asia-Centre gas pipelines. J. Hazard. Mater. 46, $57-69$.

BBC News, 2009. Gas blast causes fire in Moscow. In UK - BBC News www.bbc.com/news/uk (Data accessed: January 22, 2016).

Bubbico, R., Carbone, F., Ramírez-Camacho, J. G., Pastor, E., Casal, J., 2016. Conditional probabilities of post-release events for hazardous materials pipelines. Process Saf. Environ. Prot. 104, 95-110.

Chicago Tribune, 2005. Ford City Mall Explosion. In Featured Articles from the Chicago Tribune http://articles.chicagotribune.com/ (Data accessed: January 22, 2016).

Cooper, P. W., 1996. Explosives engineering. Wiley-VCH. New York.

Daily Kent Stater, 1979. Evacuation follows explosion. Official student newspaper of Kent State University. In Google News Archive Search www.news.google.com (Data accessed: July 6, 2015).

Deutsche Welle, 2014. Excavation worker killed in Ludwigshafen gas pipe explosion. In Deutsche Welle Germany's international broadcaster www.dw.com (Data accessed: January 22, 2016).

DOT, Department of Transportation, 2002. Corrective Action Order CPF No. 3-20021003-H. Washington, D.C. 
DOT, Department of Transportation, 2008. Rupture of Houstonia 200-Line operated by Panhandle Eastern Pipeline Company, LP, Pilot Grove, Missouri, August 25, 2008. Pipeline Failure Investigation Report No. 20090030-5319. Washington, D.C.

DOT, Department of Transportation, 2009. Corrective Action Order CPF No. 3-20091009-H. Washington, D.C.

DRC, Dakota Resource Council, 2014. Update: Pipeline Explosion in Northwest Minnesota Ruled Accidental - Valley News Live. In http://drcinfo.org/ (Data accessed: January 28, 2016).

EGIG, European Gas Pipeline Incident Data Group, 2015. Gas pipeline incidents, 9th Report of the European Gas pipeline Incident Data group (period 1970 - 2013). Doc. Number EGIG 14.R.0403.

EIA, U. S. Energy Information Administration, 2017. International Energy Statistics: Natural gas consumption. In www.eia.gov (Data accessed: March 31, 2017).

El Universal, 2011. Explosión de ducto deja cráter de 20 metros en NL. In Archivo - El Universal www.eluniversal.com.mx (Data accessed: July 6, 2015).

European Commission, 2009. Gas Coordination Group: supplies in South Eastern Europe under control after gas pipeline explosion. Official website of the European Union http://europa.eu/ (Data accessed: July 6, 2015).

Evening Independent, 1961. Workmen clean up scene of gas pipeline explosion. In Google News Archive Search www.news.google.com (Data accessed: July 6, 2015).

Exponent, 2015. PG\&E Line 118B Fresno In-Service Rupture Analysis. Exponent, Inc. Failure Analysis Associates. Doc. No. 1502991.000-7356. California.

Hansen, S. M., Nordyke, M. D., Rawson, D. E., Sherman, W. C., Spruill, J. L., Steinriede, W. L., Toman, J., 1964. Recommended explosion-crater nomenclature. Geophysics, 29 (5), 772-773.

Hemmatian, B., Abdolhamizadeh, B., Darbra, R. M., Casal, J., 2014. The significance of domino effect in chemical accidents. J. Loss. Prevent. Proc. 29, 30-38.

HInt Dossier, 2005. Gas Pipeline Explosion at Ghislenghien, Belgium. Available at: www.iab-atex.nl (Data accessed: July 1, 2015).

HSE, Health and Safety Executive, 2000. Contract Research Report 294/2000: Report on a study of international pipeline accidents. HSE Books, Liverpool, U.K.

HSE, Health and Safety Executive, 2002. Research Report 036: Report on a second study of pipeline accidents using the Health and Safety Executive's risk assessment programs MISHAP and PIPERS. Liverpool, U.K.

IGEM, Institution of Gas Engineers and Managers, 2012. Assessing the risks from high pressure Natural Gas pipelines (2nd Ed.). IGEM House. Kegworth, U.K.

James, G., Witten, D., Hastie, T., Tibshirani, R., 2013. An Introduction to Statistical Learning: with Applications in R. Springer Texts in Statistics. Springer New York.

Kletz, T., 2011. Learning from accidents. Routledge, Taylor \& Francis Group. Third Edition.

Kraus, J., 2014. A critical evaluation of risk assessment methodology for natural gas pipeline. Safety and Reliability: Methodology and Applications, CRC Press, 43-47.

Krishna, S., Krishnamurthy, R., Gao, M., 2016. Integrity of buried gas pipeline subjected to an adjacent pipe rupture event. In: International Pipelines Conference and Exposition 2016, Calgary, Canada. http://dx.doi.org/10.1115/IPC2016-64511.

Laheij, G. M. H., Chiaradia, B., Dröge, M. T., Rozendal, S., Theune, C. J., Spoelstra, M. B., 2017. Domino effects between pipelines in pipelines corridors. In 27th Institution of Chemical Engineers Symposium on Hazards 2017 (HAZARDS 27) Series No 162, 108-114, Birmingham, United Kingdom. 
Lam, C., 2015. Statistical Analyses of Historical Pipeline Incident Data with Application to the Risk Assessment of Onshore Natural Gas Transmission Pipelines. Master Thesis, Western University. Electronic Thesis and Dissertation Repository. 2925. https://ir.lib.uwo.ca/etd/2925.

Lindberg, A-N., Hansson, S. O., Rollenhagen, C., 2010. Learning from accidents - What more do we need to know? Safety Sci. 48 (6), 714-721. https://doi.org/10.1016/j.ssci.2010.02.004.

Luccioni, B., Ambrosini, D., Nurick G., Snyman, I., 2009. Craters produced by underground explosions. Comput. Struct. 87 (21-22), 1366-1373.

MHIDAS, Major Hazardous Incident Data Service, 2007. In AEA technology. London: HSE-Health and Safety Executive. U.K.

MIFACE, Michigan Fatality Assessment and Control Evaluation, 2007. Apprentice Lineman Dies When the Vibratory Plow He was Operating Struck a High Pressure Natural Gas Line. Fatality Investigation Report \#06MI207. Occupational \& Environmental Medicine, Michigan State University. Michigan.

Mohsin, R., Majid, Z., Yusof, M., 2014. Safety distance between underground natural gas and water pipeline facilities. Reliab. Eng. Syst. Saf. 131, 53-60.

Mishra, K. B., Klaus-Dieter, W., 2015. Underground gas pipeline explosion and fire: CFD based assessment of foreseeability. J. Nat. Gas Sci. Eng. 24, 526-542.

Nessim M., Zhou, W., Zhou J., Rothwell B., McLamb, M., 2004. Target Reliability Levels for Design and Assessment of Onshore Natural Gas Pipelines. ASME. International Pipeline Conference, 2004, Volumes 1, 2, and 3, 2501-2512. doi:10.1115/IPC20040321.

NewsOn6, 2013. No Injuries In Pipeline Explosion, Fire In Pittsburg County. In News On 6 Oklahoma's Own www.newson6.com (Data accessed: January 21, 2016).

NTSB, National Transportation Safety Board, 2003. Natural Gas Pipeline Rupture and Fire Near Carlsbad, New Mexico, August 19, 2000. Pipeline Accident Report NTSB/PAR-03/01. Washington, D.C.

NTSB, National Transportation Safety Board, 2011. Natural Gas Transmission Pipeline Rupture and Fire, San Bruno, California, September 9, 2010. Pipeline Accident Report NTSB/PAR-11/01. Washington, D.C.

NTSB, National Transportation Safety Board, 2013. Rupture of Florida Gas Transmission Pipeline and Release of Natural Gas, Near Palm City Florida, May 4, 2009. Pipeline Accident Brief NTSB/PAB-13/01. Washington, D.C.

NTSB, National Transportation Safety Board, 2014. Columbia Gas Transmission Corporation Pipeline Rupture, Sissonville, West Virginia, December 11, 2012. Pipeline Accident Report NTSB/PAR-14/01. Washington, D.C.

NTSB, National Transportation Safety Board, 2015. Pipeline Accident Reports. In www.ntsb.gov (Last accessed: February 29, 2016). Washington, D.C.

Peekema, R. M., 2013. Causes of natural gas pipeline explosive ruptures. J. Pipeline. Syst. Eng. Pract. 4, 74-80.

PEMEX, Petróleos Mexicanos, 2009. Diseño, construcción, inspección y mantenimiento de ductos terrestres para transporte y recolección de hidrocarburos. Technical Report NRF-030-PEMEX- 2009.

PHMSA, Pipeline and Hazardous Materials Safety Administration, 2008. Corrective Action Order CPF No. 1-2008-1004H. Washington, D.C.

PHMSA, Pipeline and Hazardous Materials Safety Administration, 2009. Corrective Action Order CPF No. 4-2009-1021H. Washington, D.C. 
PHMSA, Pipeline and Hazardous Materials Safety Administration, 2011a. Tennessee Gas Pipeline Co. - Wrinkle Bend Failure, Natchitoches Parish, LA. November 30, 2010. Failure Investigation Report. Washington, D.C.

PHMSA, Pipeline and Hazardous Materials Safety Administration, 2011b. Tennessee Gas Pipeline Co. - Internal Corrosion, East Bernard, Texas. December 8, 2010. Failure Investigation Report. Washington, D.C.

PHMSA, Pipeline and Hazardous Materials Safety Administration, 2011c. Corrective Action Order CPF No. 3-2011-1018H. Washington, D.C.

PHMSA, Pipeline and Hazardous Materials Safety Administration, 2011d. Corrective Action Order CPF No. 2-2011-1011H. Washington, D.C.

PHMSA, Pipeline and Hazardous Materials Safety Administration, 2012a. Southern Star Central Rupture, Overpressure in KS. June 30, 2005. Failure Investigation Report. Washington, D.C.

PHMSA, Pipeline and Hazardous Materials Safety Administration, 2012b. TransCanada/Bison Pipeline Natural Gas Transmission Release near Gillette, WY. July 20, 2011. Failure Investigation Report. Washington, D.C.

PHMSA, Pipeline and Hazardous Materials Safety Administration, 2012c. Corrective Action Order CPF No. 4-2012-1011H. Washington, D.C.

PHMSA, Pipeline and Hazardous Materials Safety Administration, 2013a. Tennessee Gas Pipeline Line 100-1, Batesville, Mississippi. November 21, 2011. Failure Investigation Report. Washington, D.C.

PHMSA, Pipeline and Hazardous Materials Safety Administration, 2013b. Corrective Action Order CPF No. 4-2013-1016H. Washington, D.C.

PHMSA, Pipeline and Hazardous Materials Safety Administration, 2014a. Corrective Action Order CPF No. 2-2014-1001H. Washington, D.C.

PHMSA, Pipeline and Hazardous Materials Safety Administration, 2014b. Notice of Proposed Safety Order CPF No. 3-2014-1008S. Washington, D.C.

PHMSA, Pipeline and Hazardous Materials Safety Administration, 2015a. Pipeline Failure Investigation Reports. In www.phmsa.dot.gov (Last accessed: February 29, 2016). Washington, D.C.

PHMSA, Pipeline and Hazardous Materials Safety Administration, 2015b. Notice of Proposed Safety Order CPF No. 2-2015-1001S. Washington, D.C.

PHMSA, Pipeline and Hazardous Materials Safety Administration, 2015c. Corrective Action Order CPF No. 4-2015-1009H. Washington, D.C.

Ramírez-Camacho, J. G., Pastor, E., Casal, J., Amaya-Gómez, R., Muñoz-Giraldo, F., 2015. Analysis of domino effect in pipelines. J. Hazard. Mater. 298, 210-220.

Ramírez-Camacho, J. G., Carbone, F., Pastor, E., Bubbico, R., Casal, J., 2017. Assessing the consequences of pipeline accidents to support land-use planning. Safety Sci. 87, $34-42$.

Rencher, A. C., Schaalje, G. B., 2008. Linear Models in Statistics ( $2^{\text {nd }}$ Ed. Wiley. DOI:10.1002/9780470192610.

Rodgers, J. L., Nicewander, W. A., 1988. Thirteen Ways to Look at the Correlation Coefficient, The American Statistician, 42 (1), 59-66. https://doi.org/10.1080/00031305.1988.10475524.

Shi, H., Zhang, W., Yu, Z., Huang, L., 2012. Design of parallel pipelines in second westeast natural gas pipeline project. In: 2012 9th International Pipeline Conference, pp. 139-148. Calgary Alberta, Canada. http://dx.doi.org/10.1115/IPC2012-90268.

Siler-Evans, K., Hanson, A., Sunday, C., Leonard, N., Tumminello, M., 2014. Analysis of pipeline accidents in the United States from 1968 to 2009. Int. J. Crit. Infr. Prot. 7 (4), 257-269. https://doi.org/10.1016/j.ijcip.2014.09.002. 
Silva, E. P., Nele, M., Frutuoso e Melo, P. F., Könözsy, L., 2016. Underground parallel pipelines domino effect: An analysis based on pipeline crater models and historical accidents. J. Loss. Prevent. Proc. 43, 315-331.

Sklavounos, S., Rigas, F., 2006. Estimation of safety distances in the vicinity of fuel gas pipelines. J. Loss Prev. Process. Ind. 19, $24-31$.

Spoelstra, M. B., Laheij, G. M. H., 2011. Towards a method to calculate risks of underground pipelines transporting hazardous substances. In Hazards XXII, Symposium Series, 156, 254-260. Liverpool, U.K.

St. Joseph Gazette, 1961. Wave of fright follows gas pipeline explosion. In Google News Archive Search www.news.google.com (Data accessed: July 6, 2015).

Star-News, 1974. Gas blast disrupts service. En Google News Archive Search www.news.google.com (Data accessed: January 25, 2016).

The Gazette, 2014. Excavators agree to maximum civil penalty in natural gas line accidents. En The Gazette's daily news www.thegazette.com (Data accessed: December 3, 2015).

The Intelligencer, 2014. Two Natural Gas Pipelines in Marshall County Rupture in Less Than Three Hours. En The Wheeling Intelligencer www.theintelligencer.net (Data accessed: January 21, 2016).

The People's Tribune, 2015. Pipeline Ruptures near Pike 43. In www.thepeoplestribune.com (Data accessed: January 26, 2016).

Toledo Blade, 1954. Gas pipeline blast in County Digs 10-foot-deep crater in Cornfield. In Google News Archive Search www.news.google.com (Data accessed: Julio 6, 2015).

Tonelli, S. M., Aparício, L. V., 2005. Consequence evaluation in buried natural gas pipeline. In 4th Mercosur Congress on Process Systems Engineering and 2nd Mercosur Congress on Chemical Engineering, August 2005, Rio Das Pedras, Brazil.

TSB, Transportation Safety Board, 1997. TransCanada PipeLines Limited Line 100-3, 914-millimetre (36-inch) Main Line Kilometre Post Main Line Valve 30-3 + 0.245 kilometres Line 100-4, 1,067-millimetre (42-inch) Main Line Kilometre Post Main Line Valve 30-4 + 0.220 kilometres, Rapid City, Manitoba, 29 July 1995. Commodity Pipeline Occurrence Report P95H0036. Canada.

TSB, Transportation Safety Board, 2009. Natural gas pipeline rupture TransCanada Pipeline Inc. 914-Millimeter-Diameter Pipeline Line 2 - MLV 107-2 + 6.031 KM Near Englehart, Ontario, 12 September 2009. Pipeline Investigation Report P09H0074. Canada.

TSB, Transportation Safety Board, 2011. TransCanada PipeLines Limited 914.4 Millimetre-Diameter Pipeline Line 100-2 - MLV 76-2 + 09.76 KM, Beardmore, Ontario, 19 February 2011. Pipeline Investigation Report P11H0011. Canada.

TSB, Transportation Safety Board, 2013a. Westcoast Energy Inc., carrying on business as Spectra Energy Transmission Nig Creek Pipeline, Kilometre Post 1.93 near Buick, British Columbia, 28 June 2012. Pipeline Investigation Report P12H0105. Canada.

TSB, Transportation Safety Board, 2013b. TransCanada PipeLines Limited (NOVA Gas Transmission Ltd.) North Central Corridor Loop (Buffalo Creek West Section) Chainage 27+996 m near Fort McMurray, Alberta, 17 October 2013. Pipeline Investigation Report P13H0107. Canada.

TSB, Transportation Safety Board, 2014. Natural gas pipeline rupture TransCanada Pipe Lines Limited Line 400-1 at Mainline Valve Site 402 near Otterburne, Manitoba, 25 January 2014. Pipeline Investigation Report P14H0011. Canada. 
TSB, Transportation Safety Board, 2015. Pipeline Investigation Reports. www.tsb.gc.ca (Last accessed: February 29, 2016). Canada.

Wang, Z., Fu, Z., Zou, Y., Liu, L., Liu. H., 2011. Study on risk assessment of urban gas pipeline based on domino effect. Int. Conf. Pipelines and Trenchless Technol. 1720-1727.

Wijewickreme, D., Weeraseksara, L., 2011. Pipeline Geotechnical Engineering. Environmental and Engineering Geology, vol. II. EOLSS Publishers/ UNESCO. U.K.

Xin-zhe, N., Dong-j, Y., Hong-fei., Yi-hao, C., Hao.zhou., 2013. Investigation in craters formed by explosives with different burial depth in soil. Journal of Engineering 1 (3), 53-56.

\section{FIGURE CAPTIONS}

Fig. 1. A cross-sectional view of a crater formed by the explosive rupture of a buried pipeline (adapted from Hansen et al., 1964 and Cooper, 1996).

Fig. 2. Domino effect sequences following a crater formation by the rupture of a buried NG pipeline.

Fig. 3. Distribution of entries according to the diameter and type of pipeline.

Fig. 4. Distribution of entries according to the depth of burial of the pipelines.

Fig. 5. Distribution of entries according to the operating pressure of the pipelines.

Fig. 6. Distribution of entries according to the length of rupture of the pipelines.

Fig. 7. Diagnostic plot $\log \left(C_{l}\right) \sim \log \left(L_{r}\right)+\log (D)$.

Fig. 8. Diagnostic plot $\log \left(C_{d}\right) \sim \log \left(L_{r}\right)+\log \left(B_{d}\right)+\log (D)$.

Fig. 9. Diagnostic plot $\log \left(C_{w}\right) \sim \log (D)+\log \left(B_{d}\right)$.

Fig. 10. Event tree for the release of NG from a ruptured buried pipeline.

Fig. 11. Event tree of the domino effect sequences following the formation of a crater.

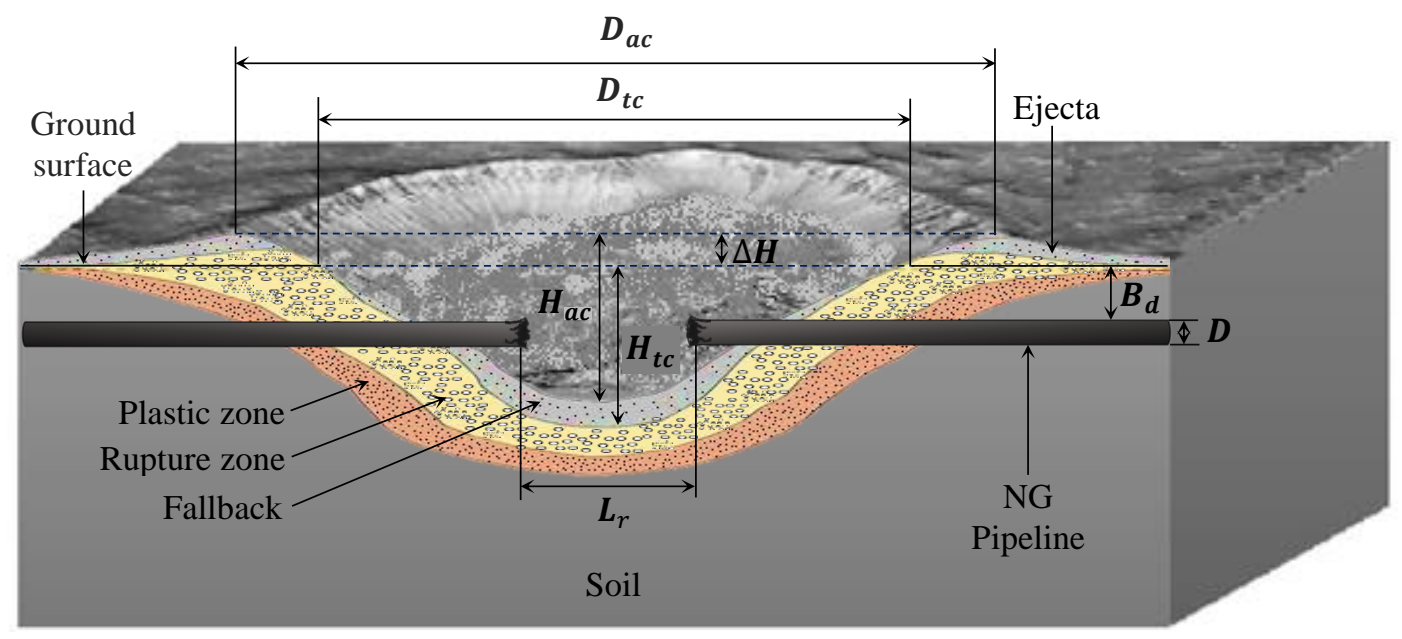

Fig. 1. 


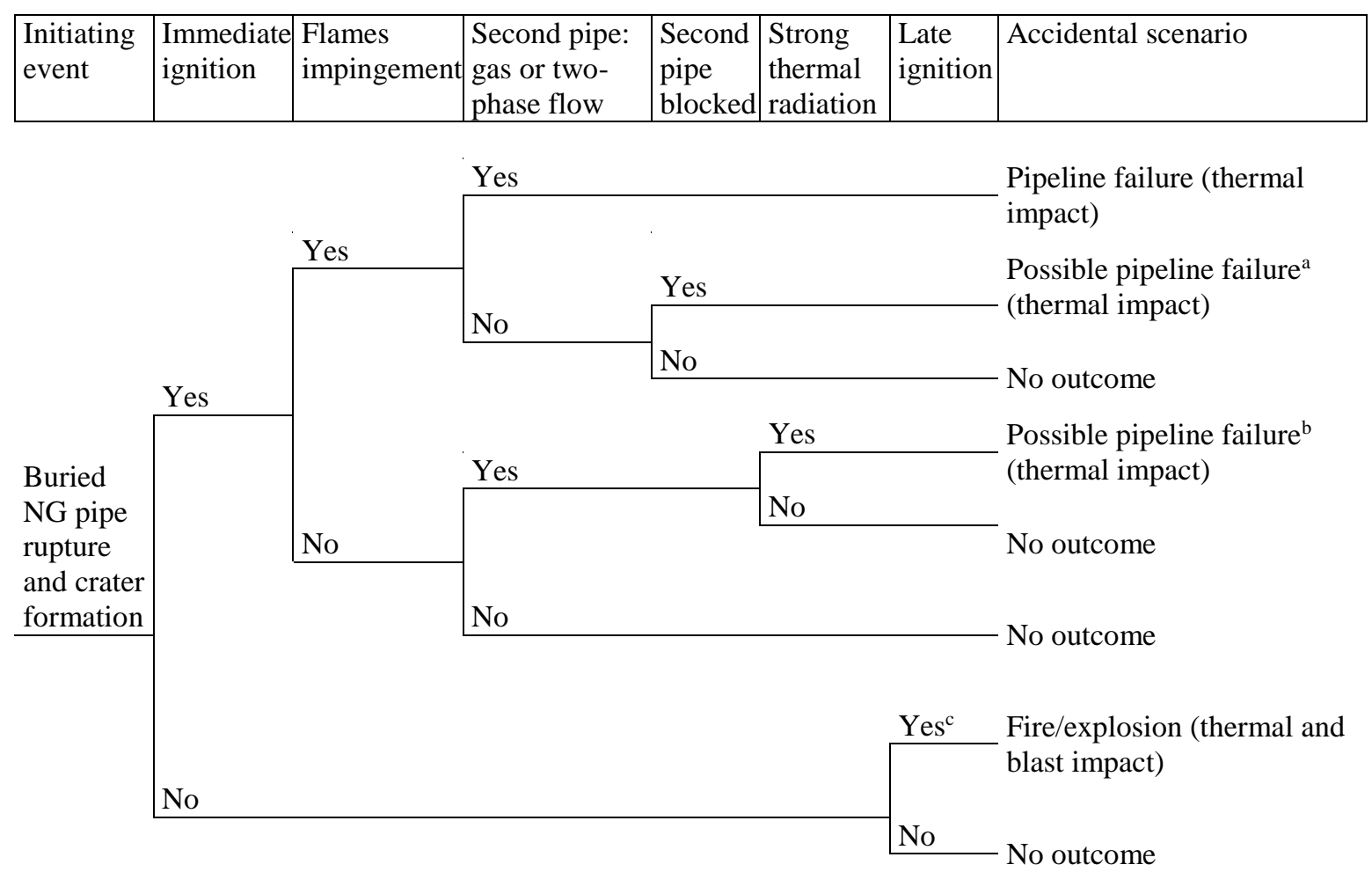

${ }^{a}$ Fire heating will increase pressure and could increase pipe wall temperature.

${ }^{\mathrm{b}}$ Heating of pipe wall could be excessive.

${ }^{c}$ Depending on meteorological conditions.

\section{Fig. 2.}

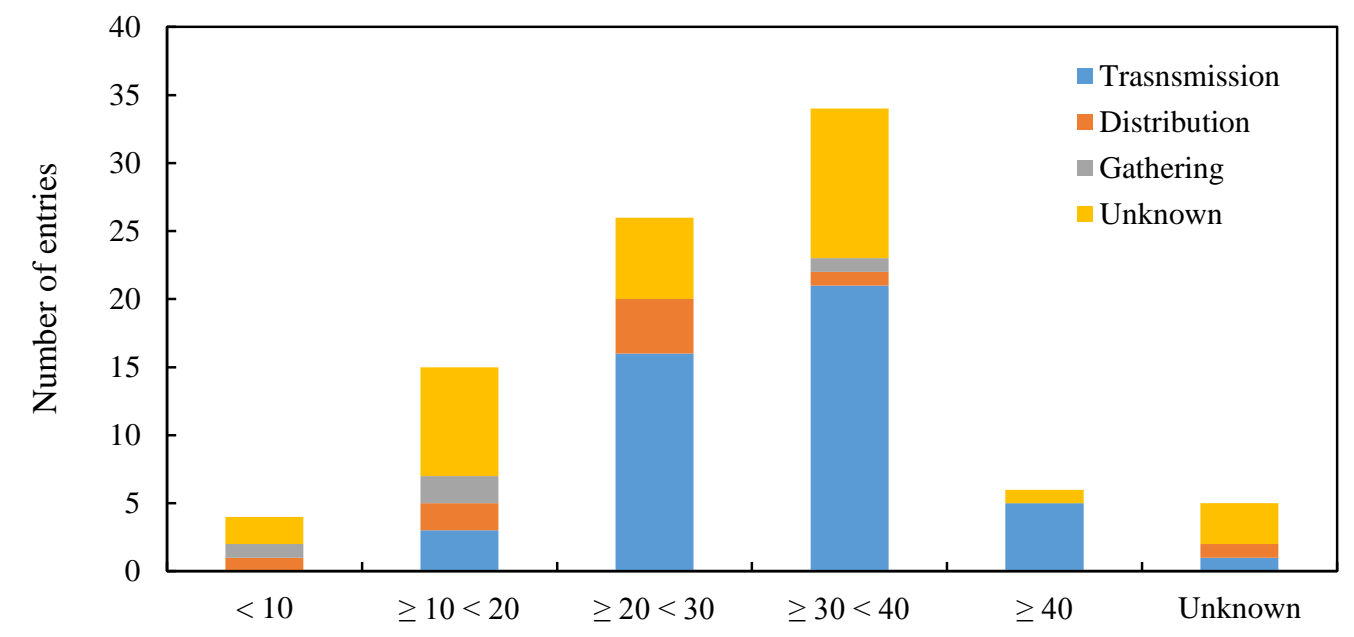

Pipeline diameter (in)

Fig. 3. 


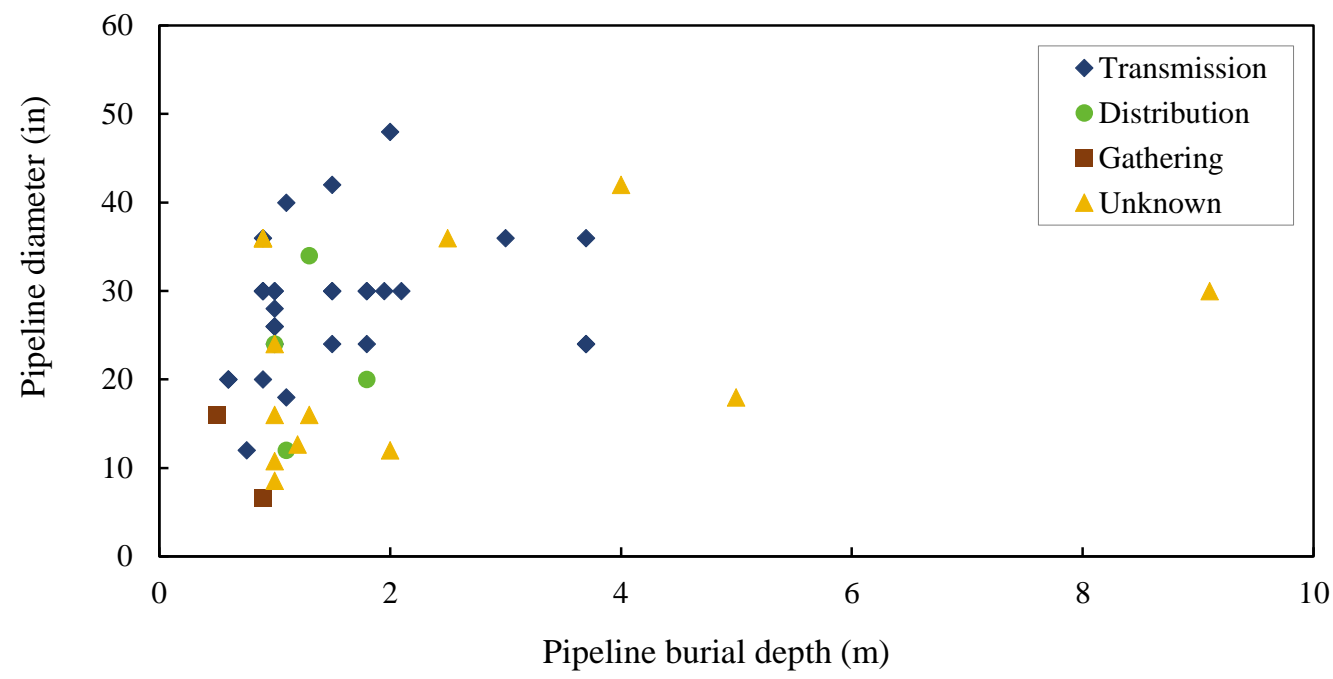

Fig. 4.

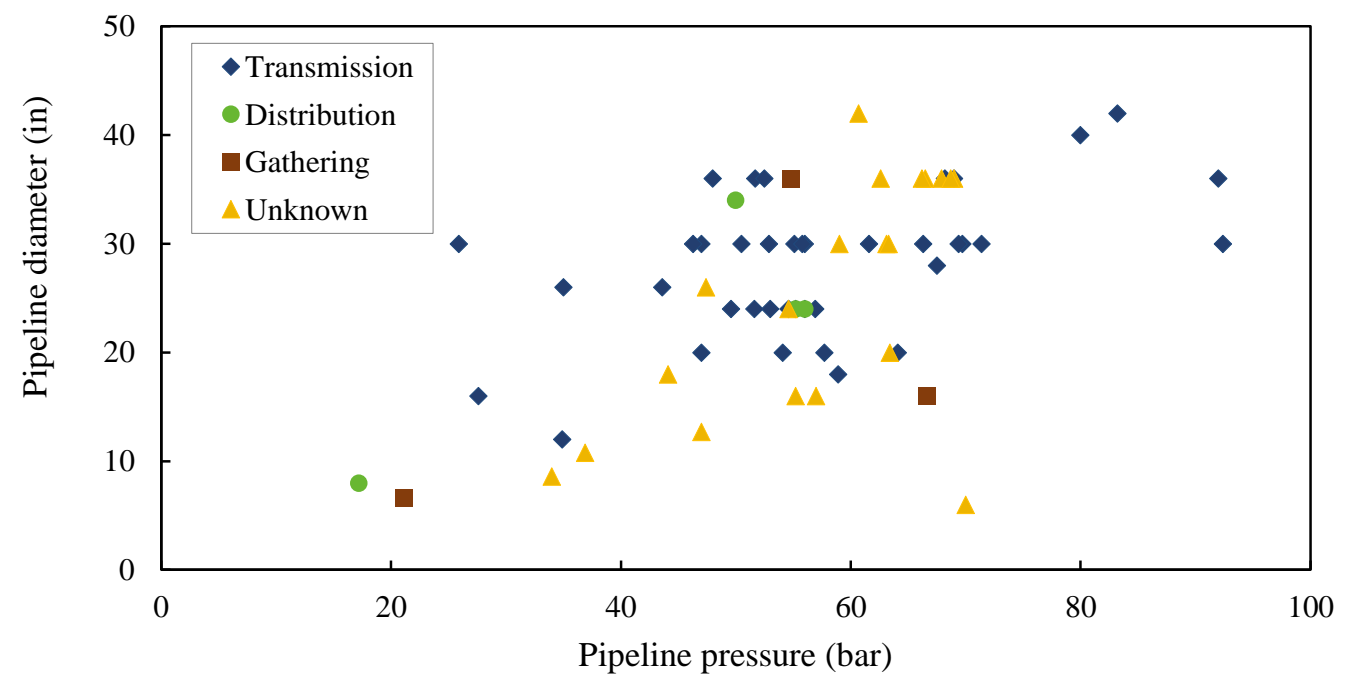

Fig. 5.

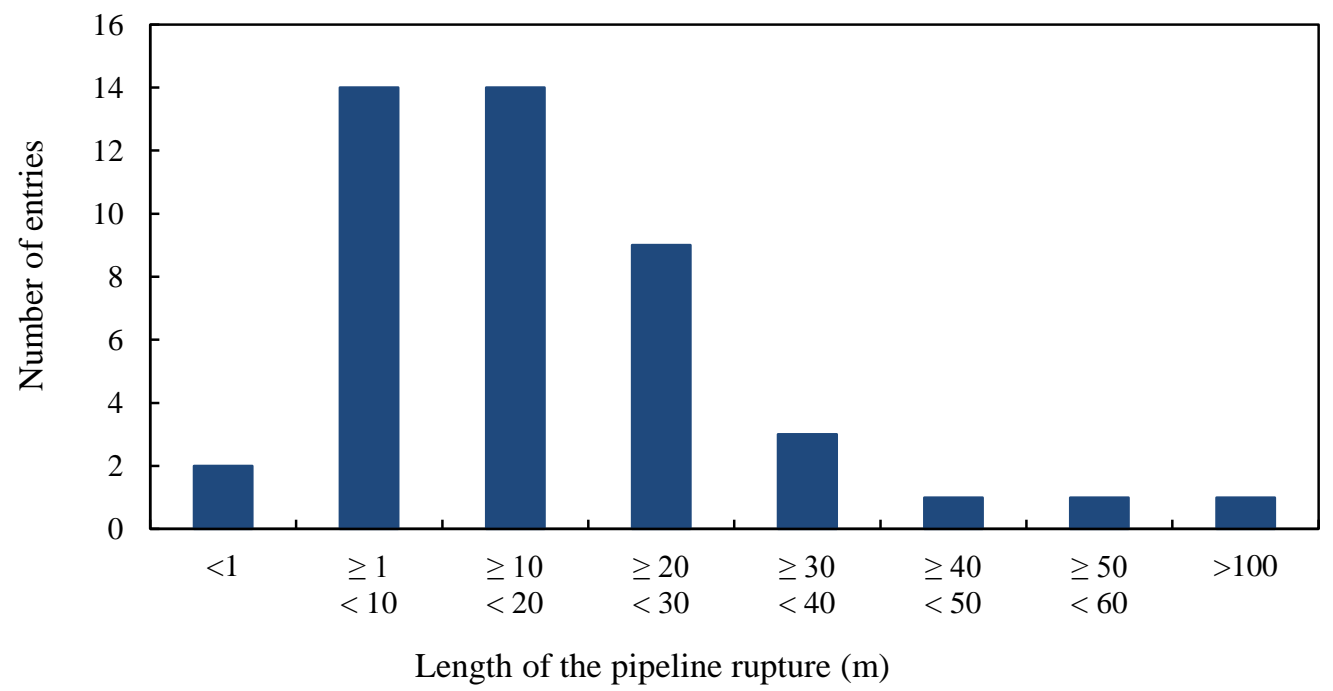

Fig. 6. 

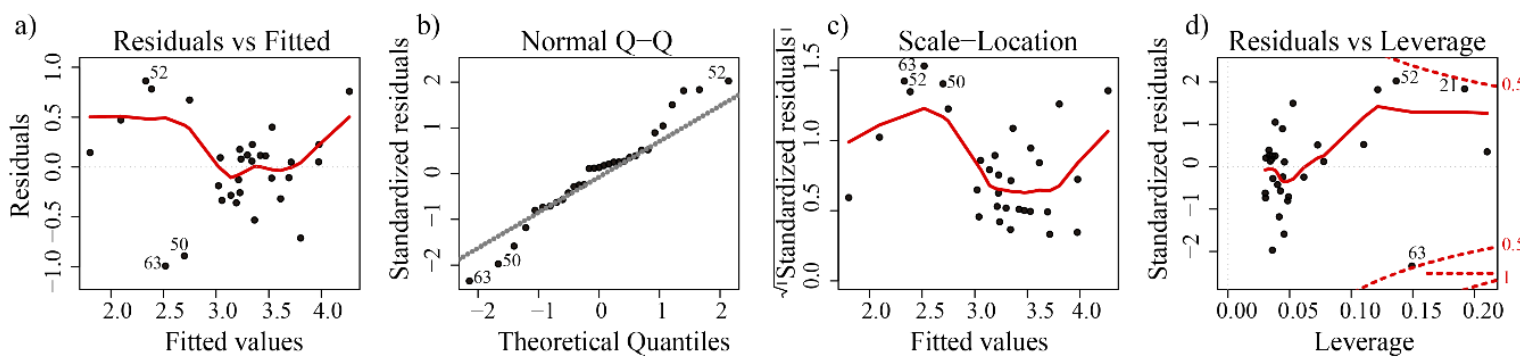

Fig. 7.
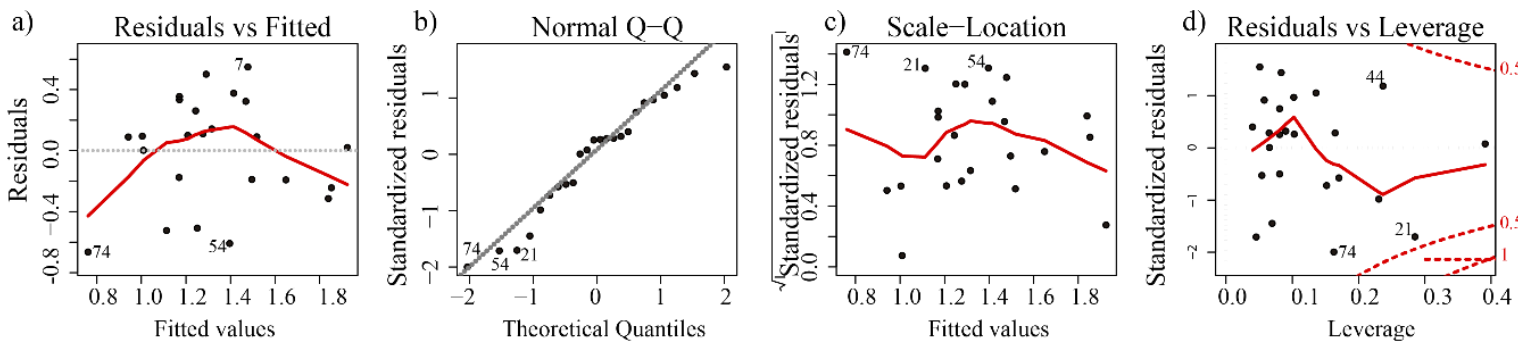

Fig. 8.
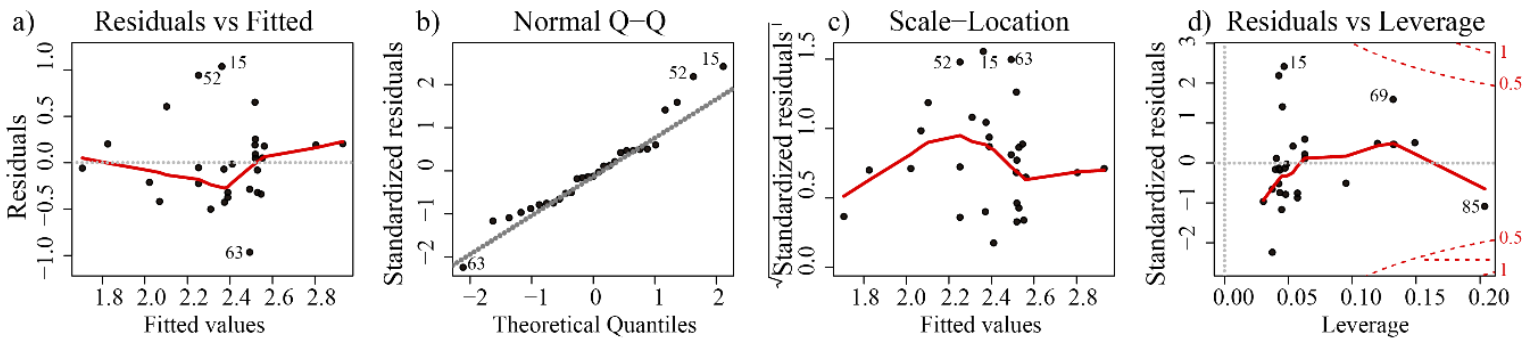

Fig. 9.

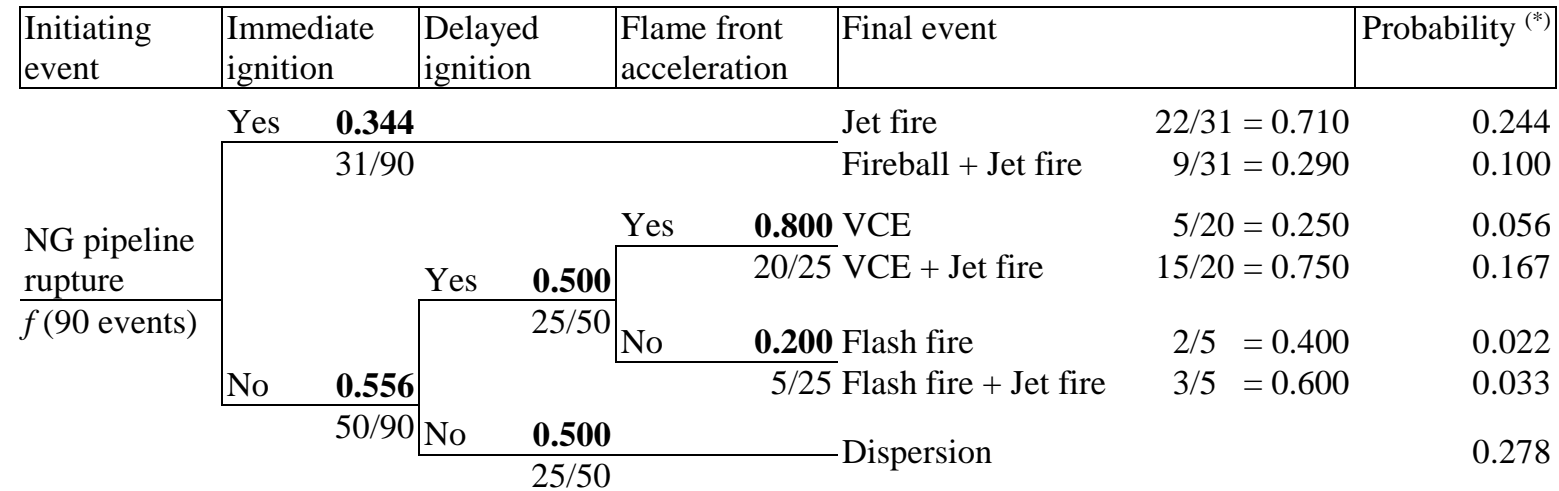

${ }^{(*)}$ Probabilities do not total 1 since the type of ignition is unknown in 9 entries.

Fig. 10 . 


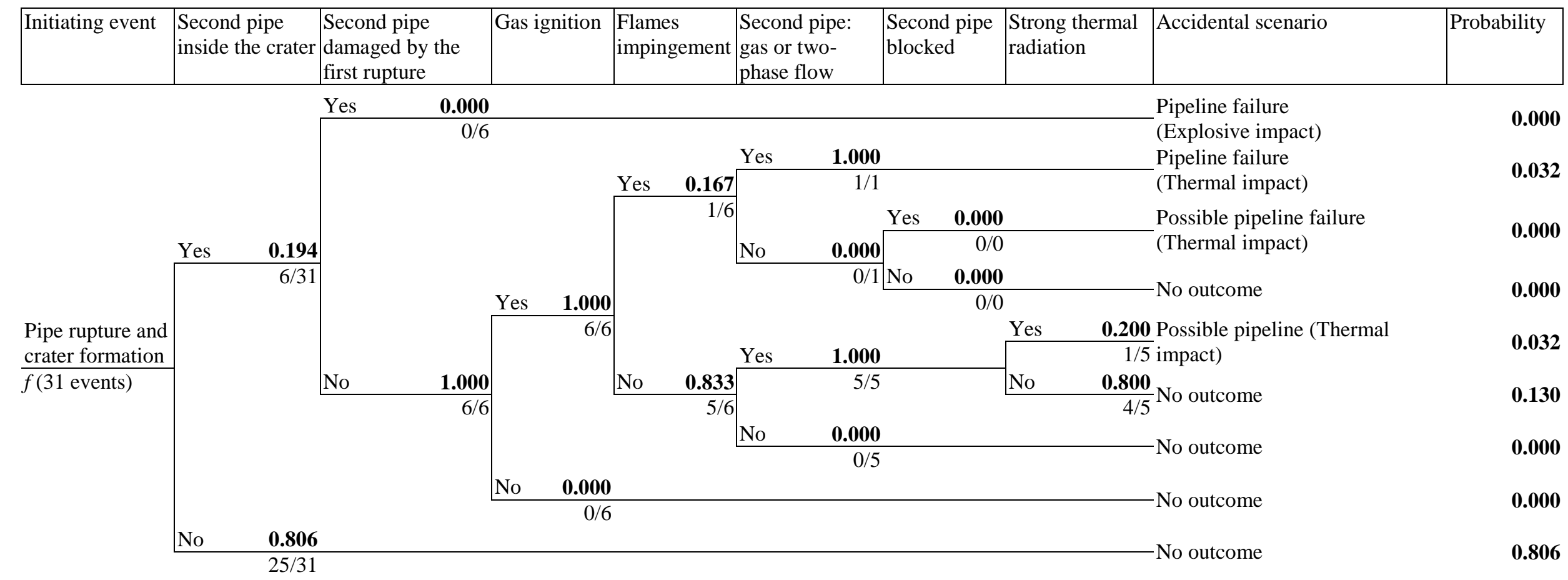

Fig. 11. 


\section{HIGHLIGHTS}

- The catastrophic rupture of a buried pipeline can create a crater.

- The formation of a crater is a relevant event due to its destructive potential.

- In parallel pipelines, the formation of a crater can lead to a domino effect.

- Influence of the pipe parameters on the resulting crater has been evaluated.

- Results obtained can be used to support distances between parallel pipelines. 